$1-1-1977$

\title{
Mineral concentration of forage species grown in central West Virginia on various soil series
}

Barton S. Baker

R. L. Reid

Follow this and additional works at: https://researchrepository.wvu.edu/ wv_agricultural_and_forestry_experiment_station_bulletins

\section{Digital Commons Citation}

Baker, Barton S. and Reid, R. L., "Mineral concentration of forage species grown in central West Virginia on various soil series" (1977). West Virginia Agricultural and Forestry Experiment Station Bulletins. 657.

https://researchrepository.wvu.edu/wv_agricultural_and_forestry_experiment_station_bulletins/558 @ WVU. It has been accepted for inclusion in West Virginia Agricultural and Forestry Experiment Station Bulletins by an authorized administrator of The Research Repository @ WVU. For more information, please contact ian.harmon@mail.wvu.edu. 
Mineral Concentration of Forage Species Grown in Central West Virginia on Various Soil Series

West Virginia University

Agricultural and

Forestry Experiment Station

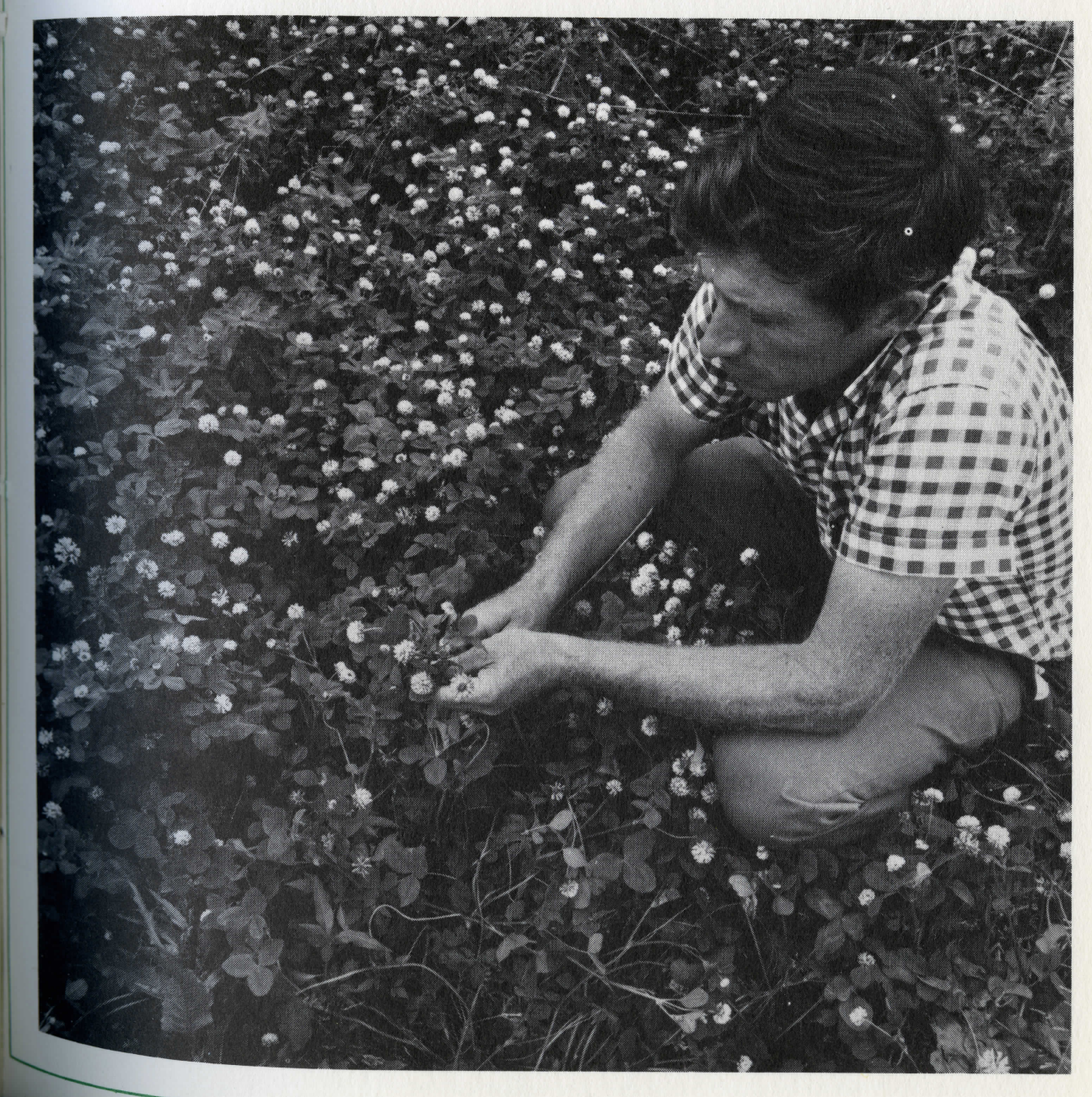




\section{AUTHORS}

Barton S. Baker is Associate Professor of Agronomy and Agronomist, Allegheny Highlands Project, Elkins, West Virginia; and R. L. Reid is Professor of Animal Science.

West Virginia University Agricultural and Forestry Experiment Station College of Agriculture and Forestry

Dale W. Zinn, Director Morgantown

\section{CONTENTS}

Summary ...............................

Literature Review ..................... 1

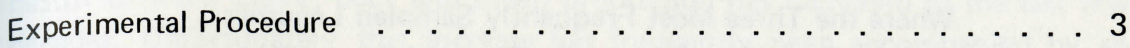

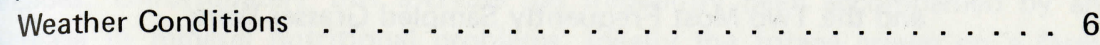

Results and Discussion . . . . . . . . . . . . 6 Soil Mineral Concentration . . . . . . . . . . . . . . 6 Mineral Concentration of Forage as Influenced by Species . . . . . . . . . 9

Mineral Concentration of Forage as Influenced by Soil Series . . . . . . 18

Forage Mineral Concentration as Influenced by

Soil Mineral Concentration . . . . . . . . . . . . . . . . . . . 19

Forage Mineral Concentration as Influenced by Maturity . . . . . . . . 29 Mineral Concentration of Forages as Influenced

by Climatic Conditions . . . . . . . . . . . . . . . . . . . . 29

Forage Mineral Concentration as Influenced by Year . . . . . . . . . 38

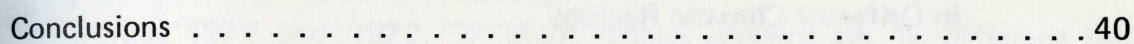

Literature Cited . . . . . . . . . . . . . . . . 41

\section{TABLES}

Table 1. Temperature and Precipitation in Four Climatic Regions

Where Plants Were Sampled ... . . . . . . . . 5

Some Properties of Soils at 27 Sampling Sites

Table 3. Mineral Concentration of Forage Species Collected, 1971 . . . 10

Table 3. (Contd.) Mineral Concentration of Forage Species Collected,

Table 4 . $1972 \ldots \ldots \ldots \ldots$. . . . . . . . . . . . 12

Table 4. Average Mineral Concentration of Legumes, Grasses and Weeds . 14

Table 5. Soil Properties Where Plant Species Collected, 1972 . . . . . . . 16

Table 6. Mineral Concentration of Legumes and Grasses Grown on

Various Soil Series, 1971. . . . . . . . . . . 20

Table 7. Percent Magnesium in Various Species When Grown on Different

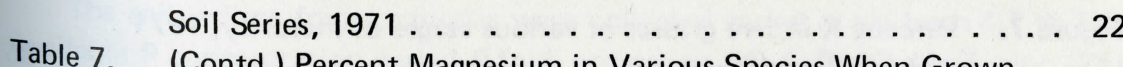

(Contd.) Percent Magnesium in Various Species When Grown

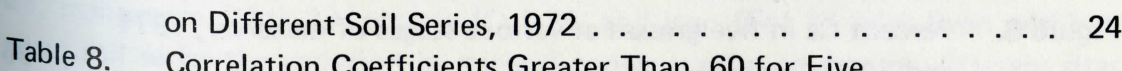

Table 8. Correlation Coefficients Greater Than .60 for Five

Frequently Sampled Species, $1971 \ldots \ldots . \ldots . \ldots 26$

Table 9. Correlation Coefficients Between Plant Magnesium and Other Parameters for Five Forage Species. 
Table 10. Average Mineral Concentration of the Three Most Frequently Sampled Legumes and the Two Most Frequently Sampled Grasses for Four Climatic

Regions, 1972.. . . . . . . . . . . . . . . . 39

Table 11. Some Properties of Soils in Four Climatic Regions Where the Three Most Frequently Sampled Legumes and the Two Most Frequently Sampled Grasses Were Grown, 1972. . . . . . . . . . . . . . . 39

\section{Appendix Tables}

Table 1. Some Properties of Soil Series Where Plants Were Collected, 1971 . . . . . . . . . . . . . . . . 47

Table 2. Some Properties of Soil Series Where Plants Were

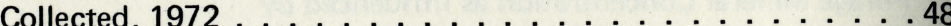

Table 3. Names of Plants Collected for Mineral Analysis . . . . . . 49

Table 4. Mineral Concentration of Forage Species at Various

Stages of Maturity $1971 \ldots \ldots$. . . . . . . . . 50 Table 4 continued through $1972 \ldots \ldots \ldots$. . . . . . . 54

Table 5. Mineral Concentration of Forage Grown on Various Soil Series in Different Climatic Regions ... . . . . . . . 58

\section{FIGURES}

Figure 1. Sites where forage samples were collected from farms in central West Virginia. Each dark circle represents an individual sampling site. . . . . . . . . . . . . . . . 4

Figure 2. Percent $P$ in three legumes at various stages of maturity, 1971 and 1972 combined. . . . . . . . . . . . . . . . 30

Figure 3. Percent $K$ in three legumes at various stages of maturity, 1971 and 1972 combined. . . . . . . . . . . . . . . 31

Figure 4. Percent $\mathrm{Ca}$ in three legumes at various stages of maturity, 1971 and 1972 combined. . . . . . . . . . . . . . . . . 32

Figure 5. Percent $\mathrm{Mg}$ in three legumes at various stages of maturity, 1971 and 1972 combined. . . . . . . . . . . . . 33

Figure 6. Percent $P$ in five grasses at various stages of maturity, 1971 and 1972 combined. . . . . . . . . . . . . . . . . . 34

Figure 7. Percent $K$ in five grasses at various stages of maturity, 1971 and 1972 combined. . . . . . . . . . . . . . . . 35

Figure 8. Percent $\mathrm{Ca}$ in five grasses at various stages of maturity, 1971 and 1972 combined. . . . . . . . . . . . . . 36

Figure 9. Percent $\mathrm{Mg}$ in five grasses at various stages of maturity, 1971 and 1972 combined. . . . . . . . . . . . . . 37

\section{SUMMARY}

The mineral concentration of forages and the availability of these minerals to livestock are important to the health of animals and also, indirectly, to the health of man. Dairy, beef and sheep production has increased in the last few decades. Unfortunately this increase has frequently been accompanied by an increase in mineral nutritional problems. Ideally the forage grown on a farm should be sufficient in all essential minerals to the extent that supplementation would not be necessary. It has been recognized for many years that supplementation of salt to provide sodium $(\mathrm{Na})$ is an essential management practice. More recently the necessity of magnesium $(\mathrm{Mg})$, calcium $(\mathrm{Ca})$, and phosphorus (P) supplementation in individual situations has been accepted by producers.

Some of the more important factors influencing mineral concentration of forage are plant species, plant maturity, season of the year, soil type, soil fertility, and climatic conditions. However, relatively few plant species and few soils have been investigated in West Virginia although many species throughout the state contribute to the diet of grazing animals, and these species grow under many different soil and climatic conditions.

During 1971 and 1972, 32 plant species growing on 14 different soil series at 27 sites in central West Virginia were analyzed for mineral concentration in order to broaden the scope of information available on the mineral concentration of forage species in the state. The sites were typical of the region and represented land that was used for pasture and hay. The sites represented four climatic areas differing in elevation, temperature, and rainfall. Species that were growing at the sampling sites were collected when they were abundant enough to provide sufficient forage for analysis.

Orchardgrass occurred most frequently of the 32 species collected and was sampled more often than any other species. Alfalfa, red clover, and timothy were found at several locations and about an equal number of samples was taken of each species. White clover was abundant at a few locations and was present at other locations although frequently not in sufficient quantities for analysis. Kentucky bluegrass and red top were present at most locations, but these species usually were not in sufficient quantities to constitute a sample. Other species collected were typically present at only a few locations.

The soils where forage samples were collected varied in $\mathrm{pH}$ from 4.7 to 7.1. Available $\mathrm{P}$ concentration varied 9-fold, potassium (K) 4, Ca 17, Mg 7, zinc $(\mathrm{Zn})$ 44, manganese $(\mathrm{Mn})$ 23, copper $(\mathrm{Cu})$ 25, and iron ( $\mathrm{Fe}) 27$-fold. Even within a given soil series the variation in mineral concentration among the different sites was considerable due to past treatment. Since the plow layer, the major area of root development for forage crops, has undoubtedly been influenced greatly by past farming practices, it was difficult to classify a particular series regarding its ability to provide a certain mineral for plant growth. 
Several factors were found to have considerable influence on the mineral concentration of the forage sampled. The most important factor, however, was species. The variation for a single mineral was frequently as great as 2 - to 10 -fold among species. When the species were grouped as legumes, grasses, and weeds it was found that the weeds contained higher concentrations of $\mathrm{P}, \mathrm{K}, \mathrm{Mg}, \mathrm{Mn}$, strontium ( $\mathrm{Sr}$ ), barium (Ba), and aluminum (Al) than the legumes or grasses. The legumes contained higher concentrations of nitrogen $(\mathrm{N}), \mathrm{Ca}, \mathrm{Mg}, \mathrm{Fe}$, boron (B), $\mathrm{Zn}, \mathrm{Cu}$, molybdenum (Mo), Sr, Ba, and Al than the grasses. The grasses contained higher concentrations of $\mathrm{K}$ and $\mathrm{Mn}$ than the legumes. Both legumes and grasses contained more $\mathrm{N}$ and $\mathrm{Na}$ than weeds.

Species within each of the groups varied considerably in the concentration of particular minerals. Among the legumes, American vetch accumulated more $P$ and $\mathrm{Zn}$ than the other legumes. Alfalfa and white clover contained high levels of $\mathrm{K}$. Alfalfa contained relatively low levels of $\mathrm{Mg}$ and red clover contained high levels. Among the grasses, barnyard grass was high in $\mathrm{Mg}$, whereas big bluestem, bromegrass, broomsedge, panicum, poverty grass, quackgrass, red top, sweet vernal, timothy, and velvet grass were all low in $\mathrm{Mg}$.

The mineral concentration of forage grown on various soil series varied considerably. However, the species present on the different soil series were not the same. The soils with high $\mathrm{pH}$ values and relatively high fertility tended to have a greater number of species present and also more legumes. Thus it appears that the greatest influence of soil series on mineral concentration of forage was on the species of plants present.

The mineral concentration of the soil did not greatly influence the mineral concentration of forage, although there were some positive correlations. Alfalfa, red clover, white clover, and orchardgrass had significantly higher Mg values at higher levels of available $\mathrm{Mg}$ in the soil, but this was not the case with timothy. In some cases the $\mathrm{Mg}$ concentration of forage appeared to be related to the status of other minerals; high soil $\mathrm{K}$ with alfalfa was associated with low plant $\mathrm{Mg}$ in 1972, but not in 1971. The Mg concentration of red clover tended to increase as available soil $\mathrm{K}$ increased.

As forage species advanced in maturity from the vegetative to the seed stage $\mathrm{N}, \mathrm{P}$, and $\mathrm{K}$ concentrations decreased as much as 50 percent in some species. In contrast, the $\mathrm{Ca}$ and $\mathrm{Mg}$ concentration increased slightly or remained constant in legumes from the vegetative to the full-bloom stage, and then decreased. In the grasses, Mg tended to be constant until flowering and then decreased. The micronutrients were not affected by advancing maturity as much as were the macronutrients. In nearly all species the mineral concentration of the regrowth was very similar to concentrations in early vegetative growth.

Forage samples from different climatic regions were quite different in mineral concentration. In some cases results appeared to be related to climatic and soil conditions existing in a region; for example, low $\mathrm{Mg}$ in forage from areas where the soil Mg was low, temperatures cool, and precipitation abundant. However, in other cases the results were unexpected; for instance high N, P, and $K$ concentrations in forage from two locations which represented extremes in terms of soil mineral concentration and climatic conditions.

There were some differences between years in the $\mathrm{N}$ and $\mathrm{Mg}$ concentration of the forage. All other elements were similar for the two years. 


\section{Mineral Concentration of Forage Species Grown in Central West Virginia on Various Soil Series}

Barton S. Baker and R. L. Reid

\section{LITERATURE REVIEW}

Underwood (25) grouped factors influencing mineral status of forage into four categories: (a) kind of plant, (b) type of soil, (c) climatic conditions during growth, and (d) stage of maturity. Allaway (1) more recently suggested five ways by which man could exercise some control over the mineral status of plants: (a) soil selection, (b) fertilization, (c) soil management, (d) crop selection, and (e) crop management. Reid et al. (19) in 1970 reviewed much of the work relating agronomic factors to the mineral composition of plants. In 1973, Fleming (7) published a comprehensive review of the mineral composition of herbage as influenced by soil, kind of plant, stage of maturity, season, temperature, fertility, and other factors. Since then additional work has been done which supports many of the general conclusions of these reviews.

Several workers have reported that legumes generally contain higher concentrations of $\mathrm{Ca}, \mathrm{Mg}, \mathrm{P}$, cobalt (Co), $\mathrm{Cu}, \mathrm{Fe}, \mathrm{Mo}$, and $\mathrm{Zn}$ than do grasses, and that the grasses contain higher concentrations of $K$ than do the legumes $(9,14$, $16,19,24)$. Different investigators have reported a close relationship between cation exchange capacity (CEC) of roots and the concentration of certain minerals within the plant $(3,17)$. Huffaker and Wallace $(12)$ reported as early as 1958 that CEC was important in cation absorption, and that legumes have a higher CEC than the grasses and tend to accumulate the divalent cations in greater concentrations than the monovalent cations. Grasses, on the other hand, tend to accumulate higher concentration of monovalent cations than divalent ones.

Even within closely related species, plants have been found to vary in mineral concentration. Hamilton and Gilbert (11) found that seven native and four introduced clovers growing at various locations in Wyoming and Montana varied as much as 5-fold in $\mathrm{Ca}$, over 4-fold in $\mathrm{Mg}$, and 7-fold in $\mathrm{Cu}$ and $\mathrm{Mn}$. $\mathrm{An}$ even greater variation existed in Co and Fe concentrations, depending on the legume species and location. Even cultivars within the same species have been found to vary in $\mathrm{Ca}, \mathrm{K}, \mathrm{Mg}, \mathrm{Mn}$, and $\mathrm{Cu}$ concentrations $(11,23)$. Manganese, $\mathrm{Zn}$, 
$\mathrm{Mg}, \mathrm{Mo}, \mathrm{Fe}$, and $\mathrm{K}$ were found by Scotter and Miltimore (21) to vary greatly among plant species that were growing on the same range and being consumed by grazing animals. Some of the variations in mineral composition due to genetic variation have recently been reviewed by Cooper (5).

Season of the year has been reported to influence the mineral concentration of herbage $(6,8,9)$. Todd $(24)$, working with timothy, orchardgrass, and ryegrass, reported that $\mathrm{Mg}$ was lowest in spring and increased in concentration as the season advanced. Magnesium concentration in clover followed the same trend but did not exhibit the same magnitude of change. It has been found that $\mathrm{Co}, \mathrm{Na}$, and $\mathrm{Mn}$, as well as $\mathrm{Mg}$, increase as season progresses (20); however, other workers $(6)$ have reported that $\mathrm{K}$ and $\mathrm{Na}$ levels in the plant decrease during the season.

Fertilization, especially with certain minerals, causes marked changes in mineral concentration of forages. Liming has been reported by John et al. (15) to decrease the concentrations of $\mathrm{Al}, \mathrm{Mn}, \mathrm{Zn}$, and Mg. Price and Moschler (18), on the other hand, reported that liming increased $\mathrm{Mg}$ in some species and lowered it in others, and that $\mathrm{Zn}$ was not influenced by liming practice. These authors concluded that soil type, plant species, and the element involved were all important considerations. In general, the addition of $\mathrm{Mo}, \mathrm{K}, \mathrm{P}, \mathrm{Ca}$, or $\mathrm{N}$ to soil tends to increase the plant concentration of the element applied (20).

The addition of some elements to the soil tends to influence the concentration of other elements in the plant. Increasing $\mathrm{N}$ concentration of the soil has been reported to increase plant $\mathrm{Mg}$ and $\mathrm{Na}(20)$. Potassium fertilization has been been reported to increase plant $\mathrm{Mg}$ and $\mathrm{Na}(20)$. Potassium $(10,20)$. The results from the application of a particular mineral, however, have not always been consistent. Increasing $\mathrm{N}$ concentration in the soil, for example, has been reported to decrease as well as increase both $K$ and $M g$ in the plant $(19,22)$. From available data it seems evident that the influence of applying one mineral to the soil on the concentration of another mineral in the plant depends on the concentration of both elements in the soil and perhaps on the concentration of other minerals in the soil or plant as well.

Soil type and physical characteristics of the soil appear to influence the mineral concentration of forages growing on the soil. Allaway (2) found that plants grown on limestone soils tend to have higher concentrations of $\mathrm{Cu}, \mathrm{Zn}$, and $\mathrm{Ca}$ than the same plants grown on either shale or clay soils. Cheng et al. (4) and $\mathrm{Ca}$ than the same plants grown on either shale or clay soils. Chenget al. (4) reported that soil temperature and moisture were positively correlated with $\mathrm{Mn}$ and $\mathrm{Fe}$ concentration in plants, but inversely related to $\mathrm{Al}$ and Mo concentration. He also reported that soil compaction has considerable influence on the results obtained at various temperatures and moisture contents. Although soil series influences mineral concentration, it is known from work of Jencks (13) that in West Virginia soils a given series varies considerably in mineral concentration and differences among series may therefore be difficult to establish.
From the research work reported in the literature it seems clear that several factors influence the mineral concentration of forages. In addition, it appears that the factors influencing mineral concentration are interrelated in such a way that the influence of a single factor can not be predicted with much accuracy unless many other factors are also known. In order to better understand the interrelationships involved, considerably more research needs to be conducted.

\section{EXPERIMENTAL PROCEDURE}

Twenty-seven sampling sites representing 14 different soil series and four regions which differ in temperature and rainfall were chosen in Randolph and Upshur counties in early spring of 1971 as locations where forage samples would be collected (Figure 1). Sampling sites were located on the farms of cooperators in the Allegheny Highlands Project and each site consisted of an area approximately $100 \mathrm{ft} \times 100 \mathrm{ft}$. Most areas were in fields where forage was harvested for hay, but some were in pastures and a few were in idle areas. During the 1971 and 1972 growing seasons forage of individual species was collected at each site when growing in sufficient quantity to constitute a sample for analysis. All plant parts 2 inches above the soil surface were combined to constitute a sample. At the time the sample was collected the stage of maturity was recorded and the plant material was placed in a paper bag. Later the same day the plant material was placed in a drier at $158^{\circ} \mathrm{F}$. After drying, the samples were ground in a Wiley mill with a stainless steel screen and stored for subsequent analysis. At the end of the growing season all forage samples were sent to the University of Georgia Soil Testing and Plant Analysis laboratory and analyzed for 15 minerals.

At the end of the 1971 growing season, or midway through the two-year sampling period, soil samples were collected and tested by United States Testing Company for $\mathrm{pH}$, percent organic matter, $\mathrm{P}, \mathrm{K}, \mathrm{Ca}, \mathrm{Mg}, \mathrm{Zn}, \mathrm{Mn}, \mathrm{Cu}$, and $\mathrm{Fe}$.

A few forage samples were taken from sites that were not among the original sites selected. This was done in order to include some species that were common in the region but not growing on the selected sites. A few species were collected from Meckesville and Zoar soil series, but the soils were not analyzed. Tall fescue was collected from a pond bank to get additional information on this species since it was growing on hardly any of the original sites.

Weather data were obtained throughout the sampling period. To help determine the influence of climatic conditions on mineral concentration, the 27 sampling sites were grouped into four climatic regions based on temperature and precipitation data (Figure 1). A summary of the climatic conditions in each region is presented in Table 1 . 


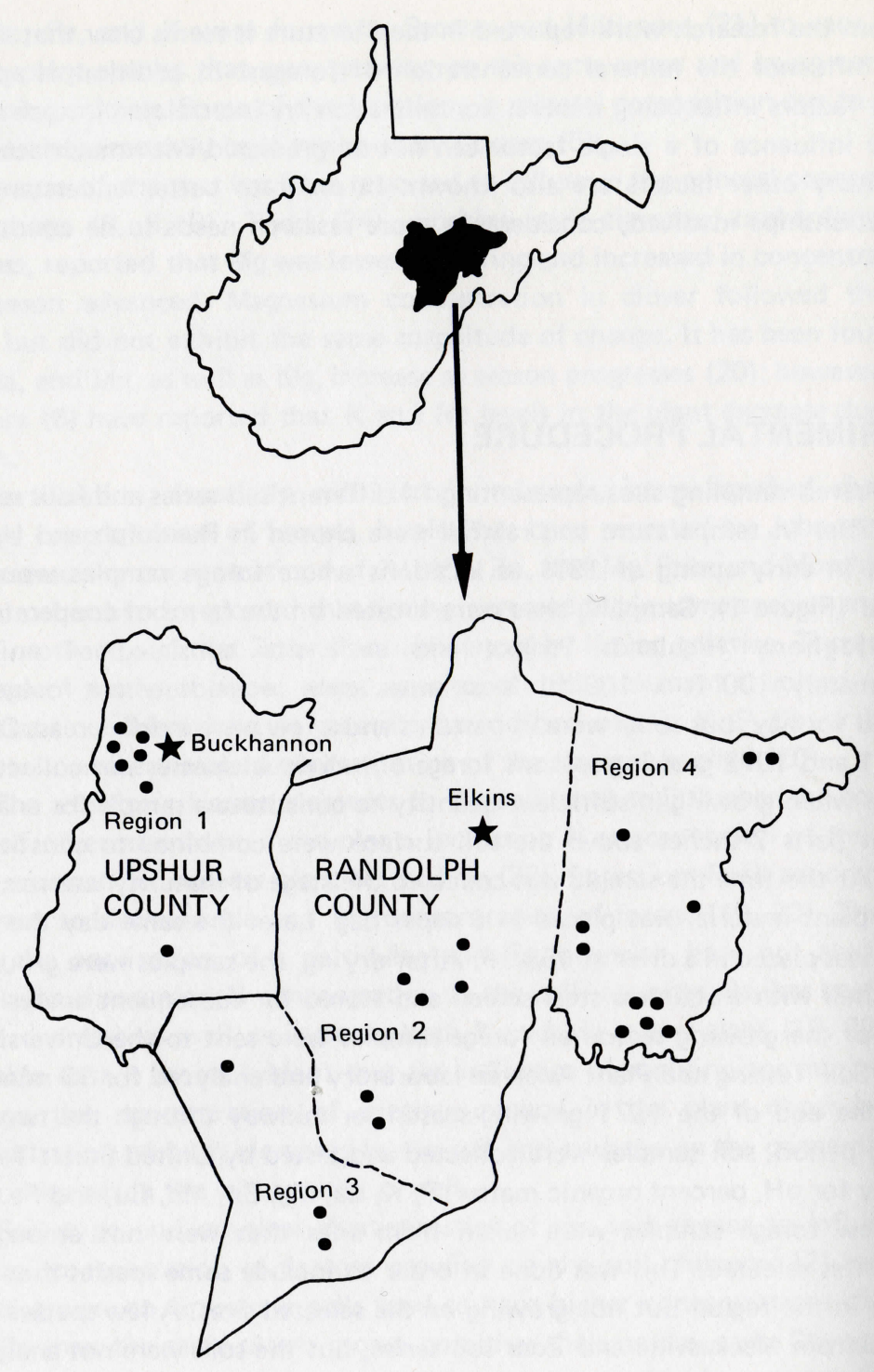

商旁 ठั ㄴำ

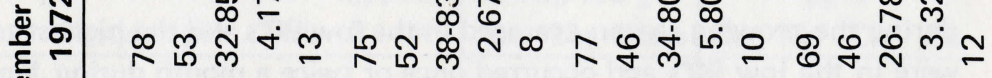
ஸे

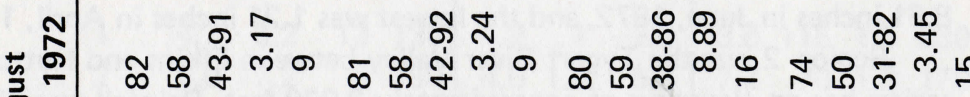
दर

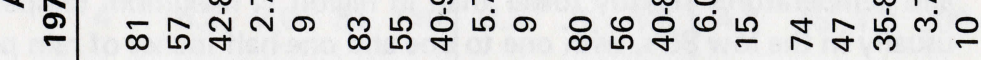

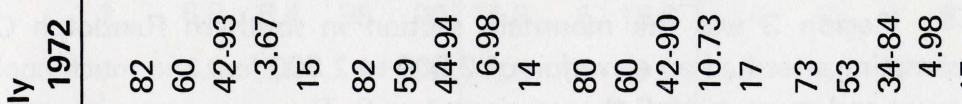
इ-

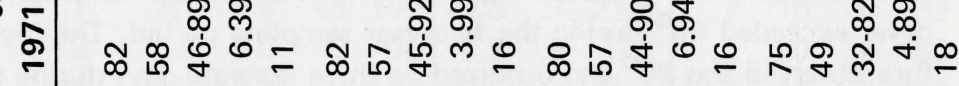

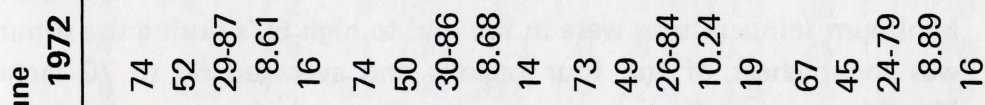

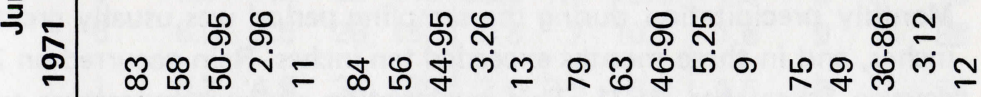
N क ल

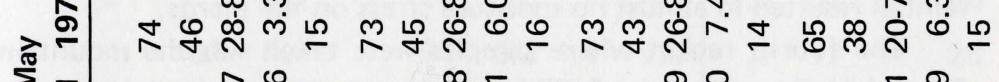
र

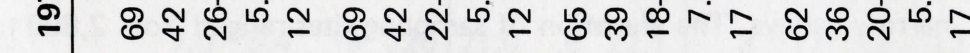

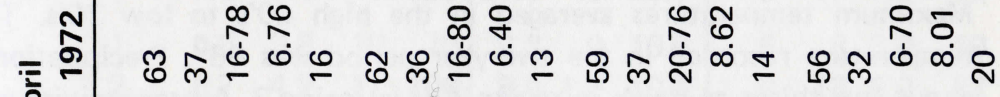
这

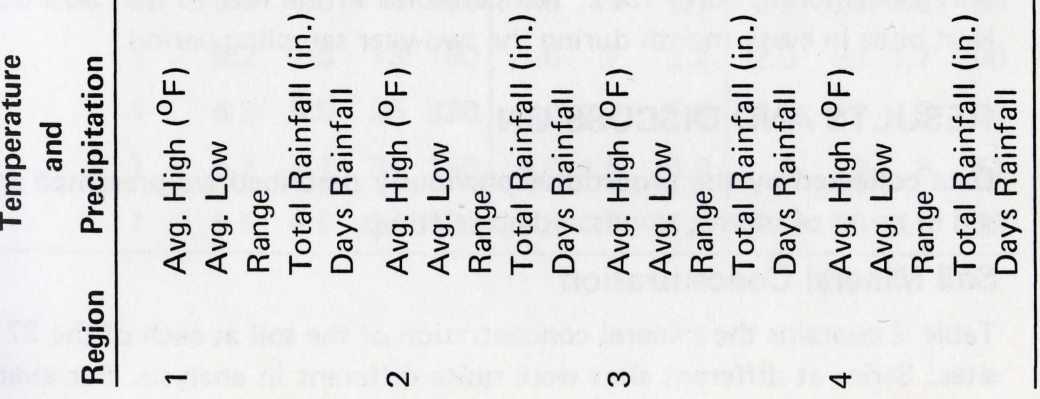




\section{Weather Conditions}

Region 1, Upshur County, was characterized by rolling to steep hill land with an elevation of approximately 1,400 feet and some of the highest temperatures of the four regions where plants were sampled. Precipitation, on the other hand was the lowest of the four regions. In general, maximum day temperatures during the growing season averaged in the low 80's and the highest temperatures were in the low 90's and occurred once or twice a month during June, July, and August. Precipitation averaged about one inch per week during 1971 and 1972.

The most precipitation for any month in this region during the two years was 8.61 inches in June, 1972, and the lowest was 1.21 inches in April, 1971.

Region 2 was the Tygart River Valley between Elkins and Huttonsville. This region has an elevation of approximately 2,000 feet. Rainfall was slightly higher and temperatures slightly lower than in region 1. Maximum temperatures were usually in the low 80's, with one to one and one-half inches of rain per week.

Region 3 was the mountain section in southern Randolph County. The sampling sites had an elevation of 2,600 to 2,800 feet and much cooler temperatures and more rainfall than regions 1 or 2 . The average maximum temperatures never exceeded $80^{\circ}$ during the two-year sampling period. The highest temperature observed was $90^{\circ}$ and occurred on three separate days during the two years. Minimum temperatures were in the mid to high 50 's during the summer. Rainfal was the highest of the four regions and averaged 60 to 70 inches per year. Monthly precipitation during the sampling period was usually greater than five inches, and in three months exceeded ten inches. Rain occurred on 23 out of 30 days in September, 1971. This combination of low temperature and abundant rainfall resulted in almost no moisture stress on the plants.

The fourth region where samples were taken was the mountain section of Randolph County east of Elkins and was characterized by steep slopes and narrow valleys. The elevation oi sampling sites ranged from 2,800 to 3,200 feet. Maximum temperatures averaged in the high 60 's to low 70 's. The highest temperature recorded in the two-year period was $86^{\circ}$. Precipitation was only about two-thirds as much in region 4 as in region 3 . Average minimum temperatures in region 4 were the lowest of the four locations, being higher than $50^{\circ}$ for only one month, July, 1972. Temperatures in the low to mid 30's occurred at least once in every month during the two-year sampling period.

\section{RESULTS AND DISCUSSION}

Data collected by the procedures previously described are presented and discussed in terms of means, trends and correlations.

\section{Soil Mineral Concentration}

Table 2 contains the mineral concentration of the soil at each of the 27 sampling sites. Series at different sites were quite different in analysis. For example, the
TABLE 2. SOME PROPERTIES OF SOILS AT 27 SAMPLING SITES

\begin{tabular}{|c|c|c|c|c|c|c|c|c|c|c|c|c|}
\hline \multirow[b]{2}{*}{ Series } & \multirow[b]{2}{*}{ Sample } & \multirow[b]{2}{*}{$\mathrm{pH}$} & \multirow{2}{*}{$\begin{array}{c}\% \\
\text { O.M. }\end{array}$} & \multicolumn{2}{|c|}{ ppm } & \multicolumn{3}{|c|}{$\mathrm{meq} / 100 \mathrm{~g}$} & \multicolumn{4}{|c|}{ ppm } \\
\hline & & & & $\mathbf{P}$ & $\mathrm{K}$ & $\mathrm{Ca}$ & $\mathrm{Mg}$ & Bases & Zn I & $\mathrm{Mn}$ & $\mathrm{Cu}$ & $\mathrm{Fe}$ \\
\hline \multirow[t]{2}{*}{ Atkins } & 1 & 6.5 & 6.6 & 52 & 270 & 5.8 & 2.5 & 9.1 & 2.2 & 11 & .8 & 48 \\
\hline & 2 & 6.2 & 5.1 & 7 & 80 & 5.6 & 2.1 & 8.0 & .5 & 6 & 1.4 & 50 \\
\hline \multirow[t]{4}{*}{ Belmont } & 1 & 4.7 & 5.2 & 13 & 130 & 1.2 & .4 & 2.0 & 3.6 & 115 & 1.5 & 230 \\
\hline & 2 & 5.0 & 7.2 & 8 & 180 & 4.0 & 1.0 & 5.5 & 7.3 & 70 & 1.3 & 170 \\
\hline & 3 & 6.0 & 6.4 & 13 & 150 & 7.6 & 1.7 & 9.7 & 1.5 & 30 & .8 & 66 \\
\hline & 4 & 5.2 & 7.0 & 31 & 140 & 3.3 & .8 & 4.5 & 4.8 & 18 & 1.2 & 200 \\
\hline Brinkerton & 1 & 6.9 & 6.4 & 38 & 90 & 14.8 & .5 & 15.6 & .4 & 8 & .4 & 67 \\
\hline Calvin & 1 & 7.0 & 3.9 & 9 & 90 & 8.5 & .4 & 9.2 & .3 & 14 & .5 & 10 \\
\hline \multirow[t]{6}{*}{ Dekalb } & 1 & 7.1 & 6.8 & 43 & 160 & 20.5 & .7 & 21.6 & .7 & 10 & .6 & 32 \\
\hline & 2 & 5.5 & 7.0 & 9 & 90 & 7.6 & .5 & 8.4 & .7 & 20 & .9 & 160 \\
\hline & 3 & 4.7 & 7.2 & 9 & 140 & 3.4 & 1.1 & 4.9 & 13.3 & 80 & 1.1 & 270 \\
\hline & 4 & 5.9 & 7.5 & 11 & 130 & 8.3 & .9 & 9.6 & 3.3 & 24 & 1.6 & 88 \\
\hline & 5 & 6.9 & 7.2 & 52 & 140 & 20.8 & 1.4 & 22.6 & 1.5 & 5 & .7 & 15 \\
\hline & 6 & 6.0 & 7.5 & 20 & 110 & 9.5 & .7 & 10.5 & 1.6 & 9 & .6 & 88 \\
\hline \multirow[t]{2}{*}{ Ernest } & 1 & 6.2 & 4.5 & 34 & 280 & 3.6 & 2.5 & 6.9 & 1.5 & 10 & .7 & 54 \\
\hline & 2 & 5.8 & 4.1 & 11 & 120 & 3.6 & .9 & 4.9 & 1.0 & 57 & .9 & 80 \\
\hline \multirow[t]{2}{*}{ Gilpin } & 1 & 6.5 & 4.1 & 7 & 90 & 5.3 & 1.4 & 7.0 & .6 & 12 & .4 & 28 \\
\hline & 2 & 6.6 & 4.3 & 21 & 130 & 9.5 & 1.9 & 11.8 & 1.1 & 11 & .5 & 24 \\
\hline Monongahela & 1 & 7.0 & 5.4 & 19 & 220 & 21.0 & .6 & 22.1 & .3 & 17 & .2 & 12 \\
\hline \multirow[t]{2}{*}{ Philo } & 1 & 6.8 & 3.8 & 19 & 70 & 9.3 & .9 & 10.5 & .5 & 8 & 3.0 & 19 \\
\hline & 2 & 6.7 & 4.2 & 17 & 100 & 8.8 & 1.3 & 10.4 & .9 & 18 & 5.0 & 32 \\
\hline \multirow[t]{2}{*}{ Pope } & 1 & 6.9 & 5.4 & 26 & 130 & 15.7 & 1.0 & 17.1 & 1.1 & 39 & .8 & 62 \\
\hline & 2 & 5.5 & 6.6 & 6 & 250 & 4.6 & .9 & 6.1 & 2.1 & 29 & 1.6 & 100 \\
\hline Purdy & 1 & 5.2 & 7.5 & 13 & 160 & 1.6 & .7 & 2.7 & 2.0 & 38 & 1.7 & 200 \\
\hline Shelocta & 1 & 6.3 & 5.9 & 25 & 320 & 5.0 & 2.7 & 8.5 & 1.5 & 21 & .5 & 36 \\
\hline Tygart & 1 & 5.7 & 5.1 & 37 & 150 & 5.0 & 1.5 & 6.9 & .5 & 9 & .6 & 51 \\
\hline Vandalia & 1 & 6.5 & 4.5 & 24 & 120 & 9.3 & 1.7 & 11.3 & 1.2 & 17 & 1.0 & 23 \\
\hline
\end{tabular}


six Dekalb series at six sites varied in $\mathrm{pH}$ from 7.1 to 4.7 , in available $\mathrm{P}$ from 9 to $52 \mathrm{ppm}$, in available Ca from 3.4 to $20.8 \mathrm{meq} / 100 \mathrm{~g}$ of soil, and in available $\mathrm{Zn}$ from .7 to $13.3 \mathrm{ppm}$. Other minerals varied in a similar fashion. This is in agreement with the work of Jencks (13), who reported considerable variation in mineral concentration within a soil series. As a result, it is difficult if not impossible to identify a particular soil series as one that may tend to provide a particular mineral and thus influence the composition of plants in a uniform way regardless of location. It does indicate that man has altered the mineral concentration in the plow layer, the major root zone, to the extent that soil series is of secondary importance in determining the present soil status of macronutrients. The soil series may, however, appreciably influence the supply of some micronutrients and may also be of considerable importance when species are grown that have roots that penetrate to the deeper horizons.

The $\mathrm{pH}$ values shown in this table are considerably higher than those reported by Jencks (13) for these series in West Virginia. However, his data were for virgin or untreated soils, which represented the native state, whereas soils studied in this investigation were ones that for the most part had been treated with lime. Soils in this study also were higher in exchangeable $\mathrm{Ca}, \mathrm{Mg}, \mathrm{P}$ and $\mathrm{K}$ than those reported for the same series in the native state. This undoubtedly is due to the addition of lime and fertilizer for crop production. For example, Jencks found virgin Dekalb soils to have available Ca values from .03 to $2.32 \mathrm{meq} / 100 \mathrm{~g}$, and available $\mathrm{Mg}$ from .15 to $.82 \mathrm{meq} / 100 \mathrm{~g}$ in the plow layer. The Ca concentration of six Dekalb soils where samples were taken in this study ranged from 3.4 to $20.8 \mathrm{meq} / 100 \mathrm{~g}$ and $\mathrm{Mg}$ varied from .5 to $1.4 \mathrm{meq} / 100 \mathrm{~g}$.

Organic matter values in this study were in the range of 3.9 to 7.5 percent. These values may be slightly higher than would normally be expected, but most sites had a thick sod cover and had been in sod for a number of years. In addition, many of these soils tested fairly high in $\mathrm{P}$ and $\mathrm{K}$ and vegetative growth was vigorous.

Little information is available regarding the micronutrient status of West Virginia soils. The United States Testing Company, which analyzed the soils in this study, indicated that according to their methods of analysis $\mathrm{Zn}$ levels of 0.8 to $4 \mathrm{ppm}$ and $\mathrm{Cu}$ values between 1 and $4 \mathrm{ppm}$ should be adequate for most crops. Using these values as guides it would appear that about $1 / 3$ of the soils in this study may be low in $\mathrm{Zn}$ and approximately $2 / 3$ may be low in $\mathrm{Cu}$. Using the same source as a guide it appears that the other micronutrients should be adequate for most plants. The micronutrient concentrations were not high enough to be considered toxic.

Appendix Tables 1 and 2 show the mineral concentration of the 14 soil series on a weighted basis according to the number of forage samples taken from each site. The two years differ because the number of samples taken at each site was not the same in 1971 as in 1972. In nearly all cases the average soil test for a series, weighted according to the number of forage samples taken, gave higher values than would the arithmetic average. This resulted because sites where soil fertility was low generally had only one or two forage species present in sufficient quantity for analysis, whereas sites with fairly high soil fertility had numerous species present. Those species present on soils with high fertility were usually not present on those with low fertility and vice versa. Consequently it is impossible to determine from this study what the mineral concentration of some species would be if grown under different fertility conditions. In most cases this is probably only a theoretical question because, in general, alfalfa will not be found on infertile soils, and poverty grass or broomsedge will not be found on the more fertile soils. Some species, however, such as timothy, velvet grass, and others may be found on both infertile and fertile soils and the influence of soil minerals upon forage mineral concentration is a practical question.

\section{Mineral Concentration of Forage as Influenced by Species}

During the two-year period, 32 different species were collected and analyzed for minerals. In 1971 and 1972, 343 and 248 samples were collected, respectively. Those species that were growing at several locations and were present through out the growing season were collected many times. Those species which were only growing at a single collection site or occurred during only a portion of the year were collected as frequently as possible, but in some cases this was only once. At many sites species other than the ones sampled were frequently growing, but not in sufficient quantity to constitute a sample for analysis.

The 32 species analyzed for minerals consisted of seven legumes, twenty grasses, and five broadleaf weeds. The common and scientific names are presented in Appendix Table 3. The mineral concentration of each species and the average mineral concentration of legumes, grasses, and weeds are given in Tables 3 and 4 .

The number of samples taken each year gives some indication of the relative abundance of particular species. Orchardgrass was by far the most abundant species each year. Alfalfa, red clover, and timothy were about equal in frequency of occurrence and were the second most abundant species. White clover was sampled less frequently than the four species listed above but much more frequently than any of the remaining species. It should be remembered that most sites were being managed for hay production. This would tend to decrease the amount of growth or even eliminate those species which have short or prostrate growth habits such as Kentucky bluegrass. Although only eight samples of this species were collected, it was present in small amounts at several other locations. 


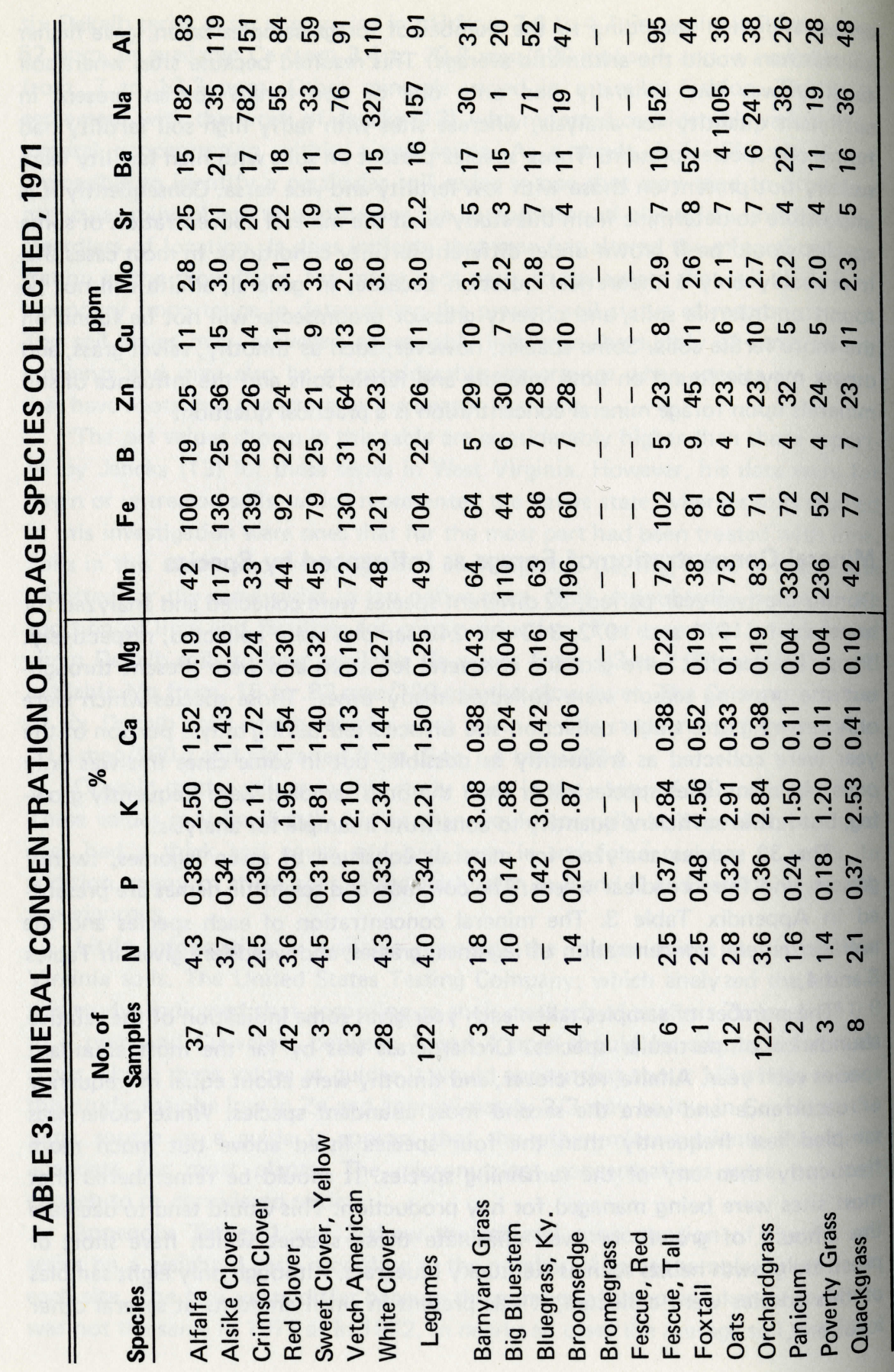

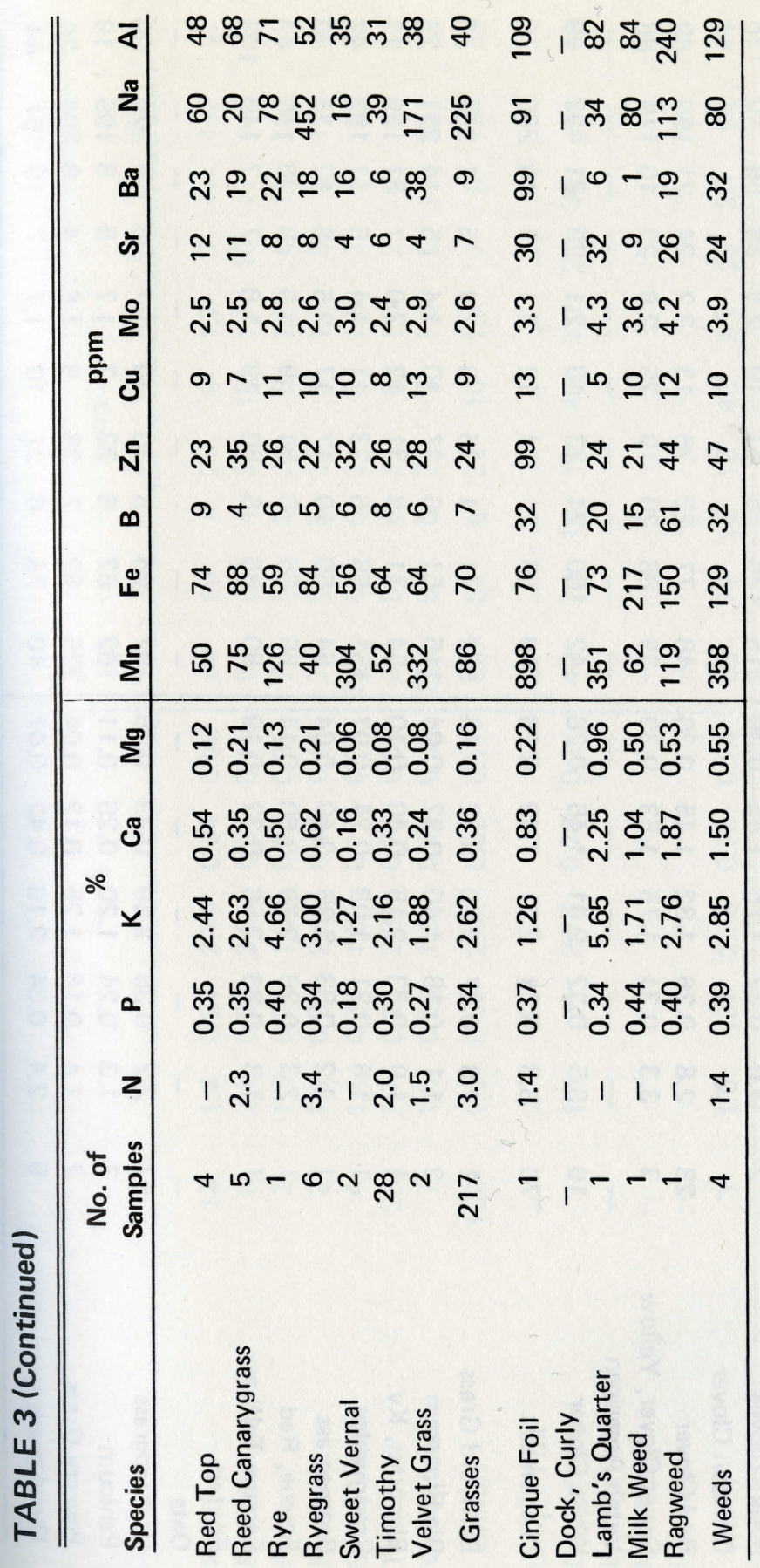



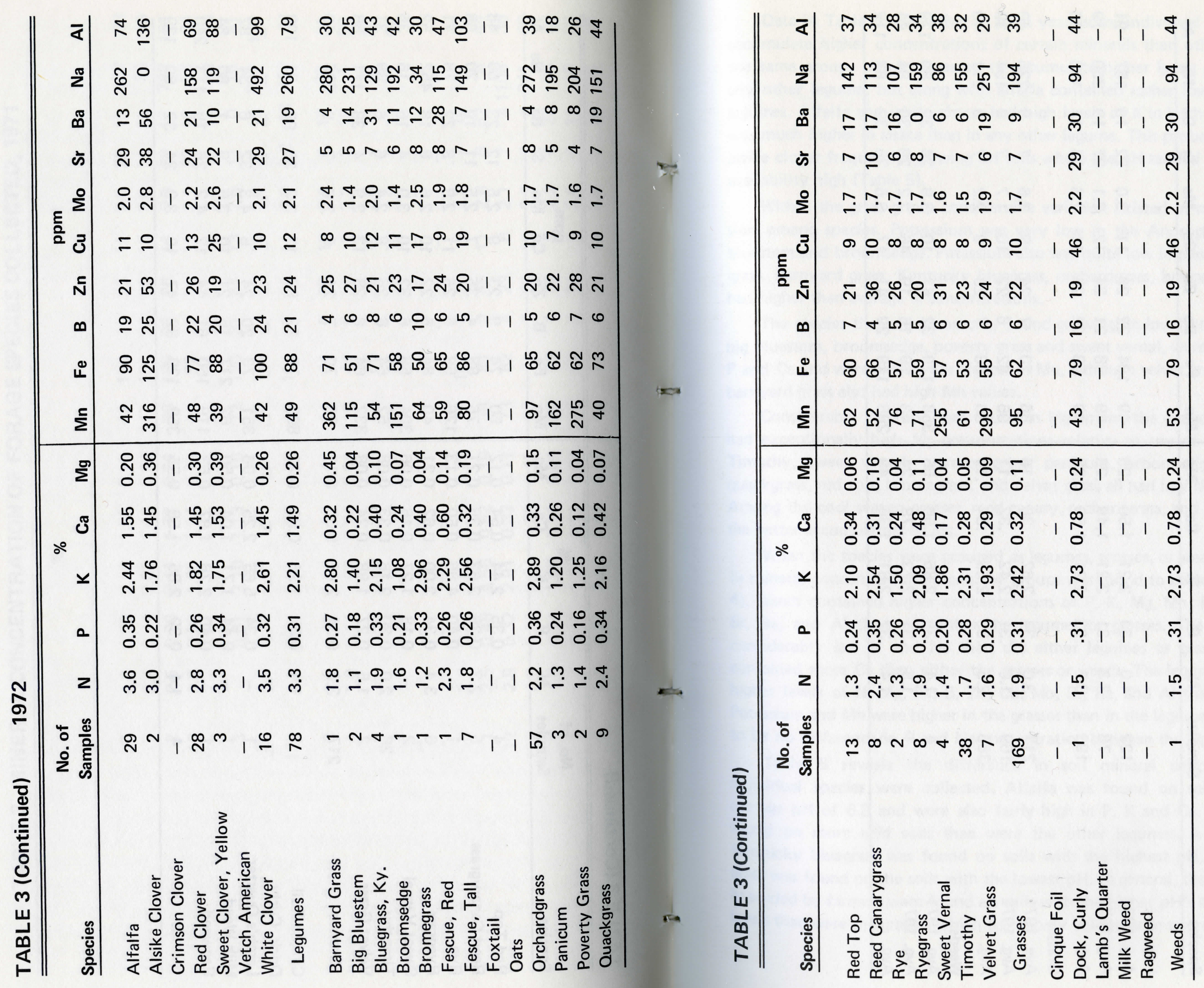


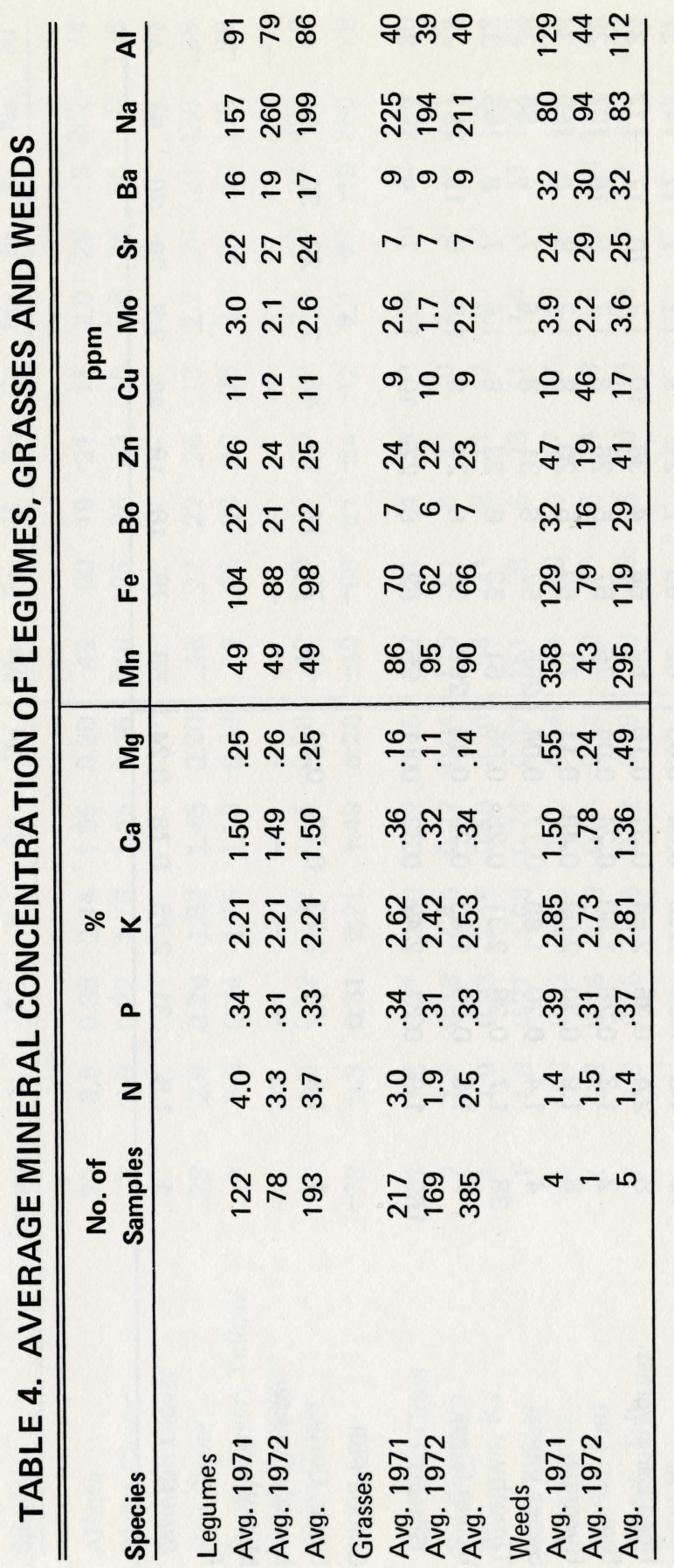

Data in Table 3 reveal that in both years some individual species seemed to accumulate higher concentrations of certain minerals than other species within the same group. Vetch appeared to accumulate higher levels of $\mathrm{P}$ and $\mathrm{Zn}$ than any other legume, but along with alfalfa contained rather low levels of $\mathrm{Mg}$ for legumes. Alfalfa and white clover had high levels of $K$ in both years. Manganese was much higher in alsike than in any other legume. This probably resulted from alsike clover frequently growing on soils where the $\mathrm{pH}$ tended to be low and $\mathrm{Mn}$ availability high (Table 5).

Within the grass group considerable variation existed in mineral concentration among species. Potasssium was very low in the Andropogon species, big bluestem and broomsedge. Potassium also was quite low in panicum and poverty grass. Barnyard grass, Kentucky bluegrass, orchardgrass, bromegrass, and foxtail had higher than average K concentrations.

The species that are commonly found growing on low fertility soils, such as big bluestem, broomsedge, poverty grass and sweet vernal, were very low in both $\mathrm{P}$ and $\mathrm{Ca}$ and were among the highest in $\mathrm{Mn}$, although velvet grass, panicum, and barnyard grass also had high $\mathrm{Mn}$ values.

Considerable variation was found in $\mathrm{Mg}$ among the grasses. Barnyard grass had exceptionally high $\mathrm{Mg}$ concentrations relative to any of the other grasses. Timothy, sweet vernal, poverty grass, panicum, broomsedge, big bluestem, quackgrass, red top, bromegrass, and velvet grass all had low $\mathrm{Mg}$ concentrations. Among the cool season grasses, reed canary, orchardgrass, and fescue seem to be the better accumulators of $\mathrm{Mg}$.

When the species were grouped as legumes, grasses, or weeds, the difference in mineral concentration among the groups was found to be considerable (Table 4). Weeds contained higher concentrations of $\mathrm{P}, \mathrm{K}, \mathrm{Mg}, \mathrm{Mn}, \mathrm{Fe}, \mathrm{B}, \mathrm{Zn}, \mathrm{Cu}, \mathrm{Mo}$, $\mathrm{Sr}, \mathrm{Ba}$, and $\mathrm{Al}$ than did either the legumes or grasses. The weeds contained considerably less $\mathrm{N}$ and $\mathrm{Na}$ than did either legumes or grasses. The legumes contained more $\mathrm{Ca}$ than either the grasses or weeds. The legumes also contained higher levels of $\mathrm{N}, \mathrm{Mg}, \mathrm{Fe}, \mathrm{B}, \mathrm{Zn}, \mathrm{Cu}, \mathrm{Mo}, \mathrm{Sr}, \mathrm{Ba}$, and $\mathrm{Al}$ than did the grasses. Potassium and $\mathrm{Mn}$ were higher in the grasses than in the legumes. There appeared to be no difference in $\mathrm{P}$ and $\mathrm{Na}$ concentration between the legumes and grasses.

Table 5 reveals the difference in soil mineral concentrations where individual species were collected. Alfalfa was found on soils which had an average $\mathrm{pH}$ of 6.8 and were also fairly high in $\mathrm{P}, \mathrm{K}$ and Ca. Alsike clover was found on more acid soils than were the other legumes. Among the grasses, Kentucky bluegrass was found on soils with the highest $\mathrm{pH}$, whereas, poverty grass was found on the soils with the lowest $\mathrm{pH}$. In general, the species commonly seeded by farmers were found on soils with the higher $\mathrm{pH}$ 's and higher mineral levels than were the grasses which commonly volunteer in swards. 


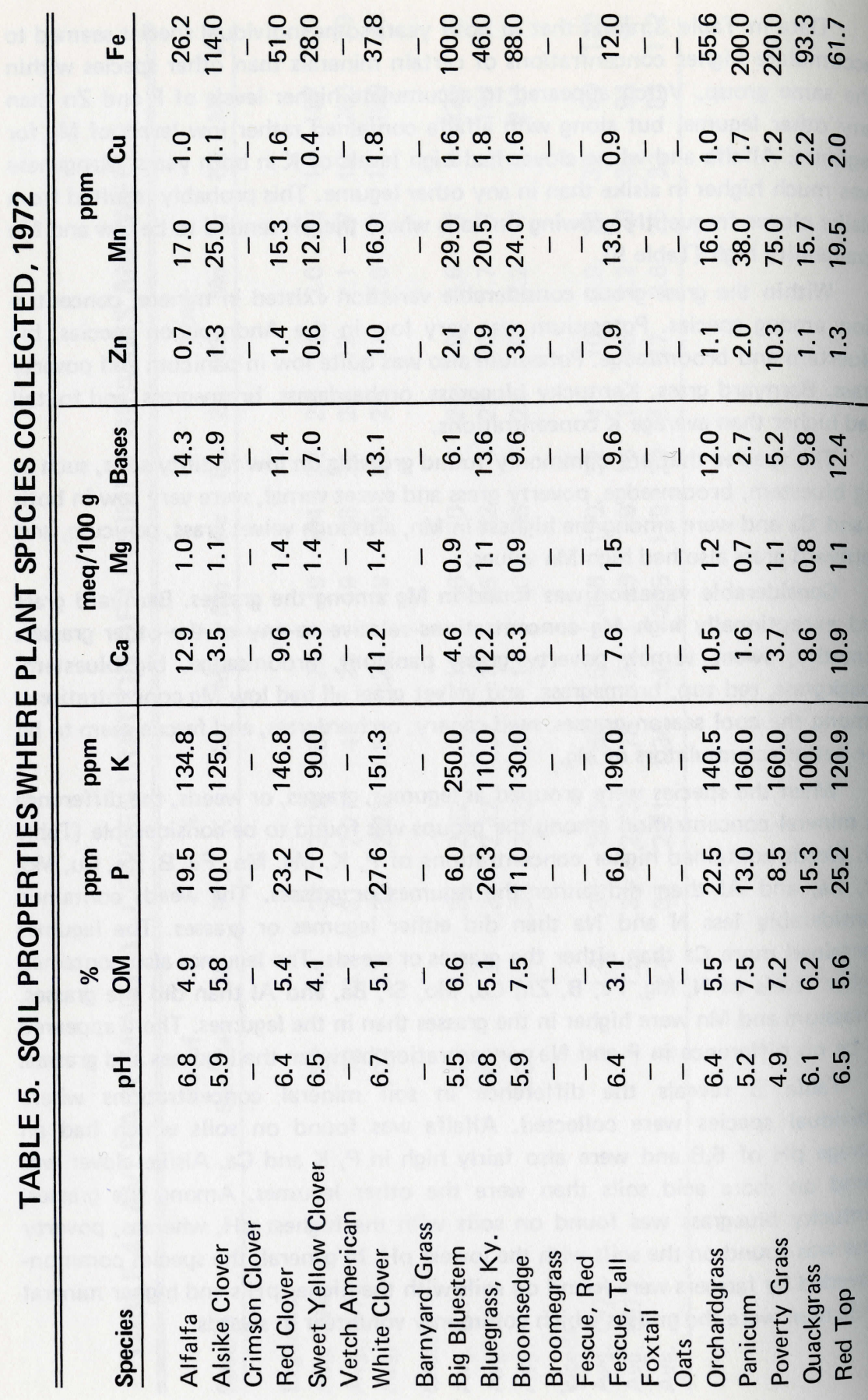

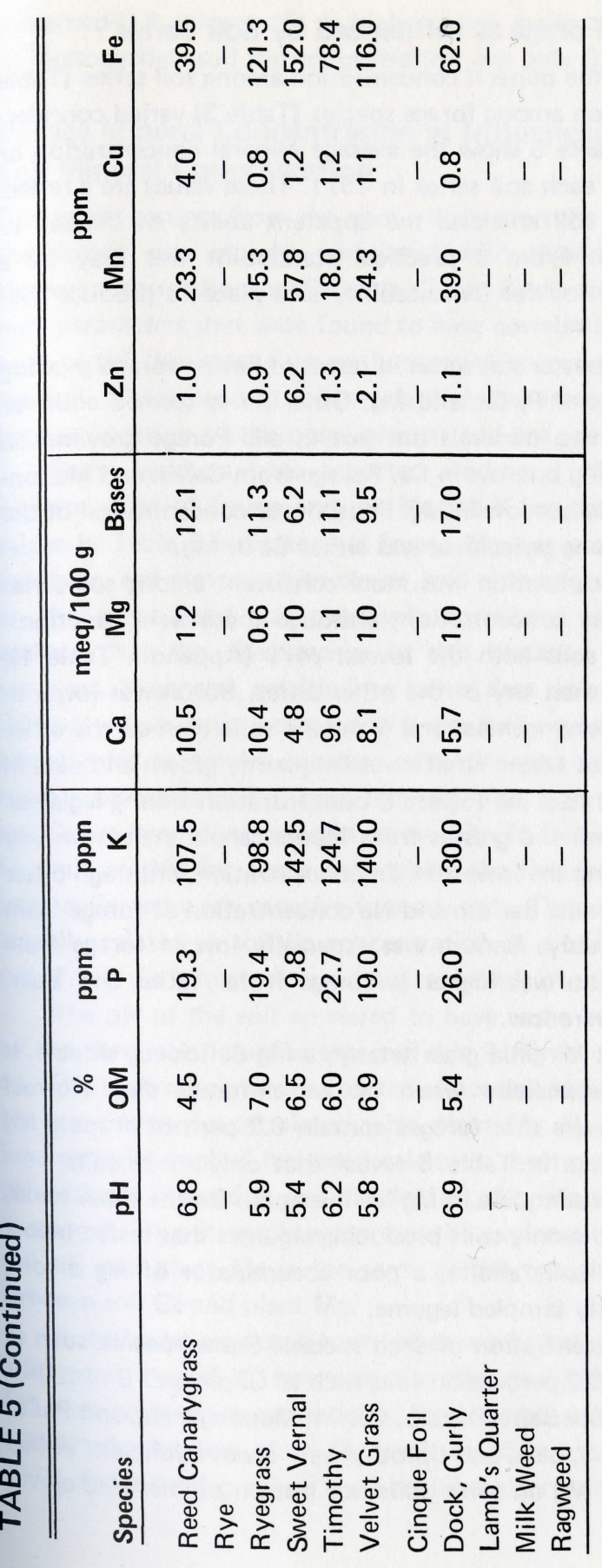




\section{Mineral Concentration of Forage as Influenced by Soil Series}

As previously discussed, both the mineral concentration among soil series (Table 2) and the mineral concentration among forage species (Table 3) varied considerably. The data presented in Table 6 show the average mineral concentration of legumes and grasses grown on each soil series in 1971. These values are a reflection of species grown on the soil and also the apparent ability of the soil to provide the various minerals. From a practical standpoint this may be a beneficial way of evaluating a soil for its suitability as a place to produce livestock feeds.

Gilpin seemed among the better soil series in terms of having forage growing on it that provided high levels of $\mathrm{P}, \mathrm{Ca}$, and $\mathrm{Mg}$. Other series seemed equal or superior to Gilpin in one or two minerals but not in all. Forage growing on Atkins soil was high in $\mathrm{P}$ and $\mathrm{Mg}$ but low in Ca. Forage from Calvin and Monongahela soils was high in $\mathrm{P}$ and $\mathrm{Ca}$ but low in $\mathrm{Mg}$. Phosphorus concentration of the forage was more consistent among series than was either $\mathrm{Ca}$ or $\mathrm{Mg}$.

Forage micronutrient concentration was more consistent among soil series than was forage macronutrients concentration, although there were variations. Belmont and Purdy, the two soils with the lowest pH's (Appendix Table 1), produced forage higher in $\mathrm{Mn}$ than any of the other series. Boron was lower in forages produced on Calvin, Monongahela, and Vandalia soils than on the other series. These were also the series where alfalfa was frequently grown and data in Table 3 reveal that this species had the lowest B concentration among legumes. Zinc was lower in both legumes and grasses from Monongahela than from any other soil. This series was among the lowest in $\mathrm{Zn}$ concentration, although other series also contained low $\mathrm{Zn}$ levels. Barium and $\mathrm{Na}$ concentration of forage from different soils varied considerably. Barium was especially low in forage from Calvin and Dekalb soils. Sodium was higher in forage from Atkins and Zoar, although in general Na values were low.

Throughout much of West Virginia grass tetany, a Mg deficiency disease, is common among beef cows, especially when on an all-forage diet. Normal recommendations for the state are that forages contain 0.2 percent or more $\mathrm{Mg}$ in order to prevent tetany. Data in Table 6 reveal that only three soils were producing grass forage that was adequate in $\mathrm{Mg}$ for livestock. On the other hand, Calvin and Monongahela were the only soils producing legumes that tested below 0.2 percent $\mathrm{Mg}$ and on both soils alfalfa, a poor accumulator of $\mathrm{Mg}$ among legumes, was the most frequently sampled legume.

Table 7 shows the $\mathrm{Mg}$ concentration of each species. Some species, such as alfalfa, contained in excess of 0.2 percent on soils such as Gilpin and Ernest, but were quite low on other soils, especially Dekalb, Calvin, Monongahela, and Philo. Other species such as velvet grass, oats, and timothy were always deficient in $\mathrm{Mg}$. Some species were deficient in $\mathrm{Mg}$ on some soils but not on others. Red clover contained 0.2 percent $\mathrm{Mg}$ or higher when grown on most soils, but when grown on Monongahela soil the concentration was only 0.16 percent

\section{Forage Mineral Concentration as Influenced by}

\section{Soil Mineral Concentration}

One might assume from the above discussion that the mineral concentration of the forage was closely correlated with mineral concentration in the soil. However, correlation coefficients (Table 8 ) do not show this to be the case. The only parameters that were found to have correlation coefficients as high as .60 in each of the five most frequently sampled species were soil Ca with total bases in the soil. These are not independent measurements since $\mathrm{Ca}$ values constitute a large proportion of the bases present and are used in calculating the total bases.

Some workers have reported finding a close relationship between $\mathrm{Mg}$ concentration of forage and the $\mathrm{Mg}$ and $\mathrm{K}$ concentration of the soil. Correlation values in Table 9 indicate that forage $\mathrm{Mg}$ was positively correlated with soil $\mathrm{Mg}$ in alfalfa, red clover, white clover, and orchardgrass, but not in timothy. Soil $\mathrm{Ca}$ on the other hand was negatively correlated with plant Mg. It seems to the authors that the relationship in this instance is related to previous liming practices. In general, calcitic lime rather than dolomite has been used in the area. Calcium values have increased as a result of applying calcitic lime, but Mg values have tended to remain constant or to decrease slowly as $\mathrm{Mg}$ was removed from the soil by leaching and crop removal. This has resulted in a situation where $\mathrm{Mg}$ and $\mathrm{Ca}$ are inversely related in many soils. In fact, correlation values between soil $\mathrm{Ca}$ and soil $\mathrm{Mg}$ for those soils where the five most frequently sampled species were collected were negative in every case. Therefore, forage $\mathrm{Mg}$ is probably not actually related to soil Ca concentration in a cause and effect relationship, but rather, soil $\mathrm{Ca}$ is related to soil $\mathrm{Mg}$ as a result of previous liming practices.

The $\mathrm{pH}$ of the soil appeared to have some bearing on plant $\mathrm{Mg}$ as indicated by the correlation coefficients in Table 9. As soil $\mathrm{pH}$ increased plant $\mathrm{Mg}$ decreased. This at first seems unexpected, since soil $\mathrm{Mg}$ would tend to raise $\mathrm{pH}$ and soil $\mathrm{Mg}$ was positively correlated with plant Mg. However, as discussed earlier, the lime material applied has been calcite in most cases and this has tended to raise $\mathrm{pH}$ without increasing soil $\mathrm{Mg}$. In fact, $\mathrm{Mg}$ relative to $\mathrm{Ca}$ and $\mathrm{pH}$ has probably decreased. Thus it would seem that the explanation for the relationship between soil $\mathrm{pH}$ and plant $\mathrm{Mg}$ is the same as the one given earlier for the relationship between soil $\mathrm{Ca}$ and plant $\mathrm{Mg}$.

It might be expected from other work that plant Mg would be appreciably influenced by soil $\mathrm{K}$; however, the relationship between these two factors was not consistent. In some species, for example alfalfa in 1972, high soil K was associated with low plant $\mathrm{Mg}$ level. In other species, for example red clover in 1971, the plant Mg values were positively correlated with soil K. Thus it appears 


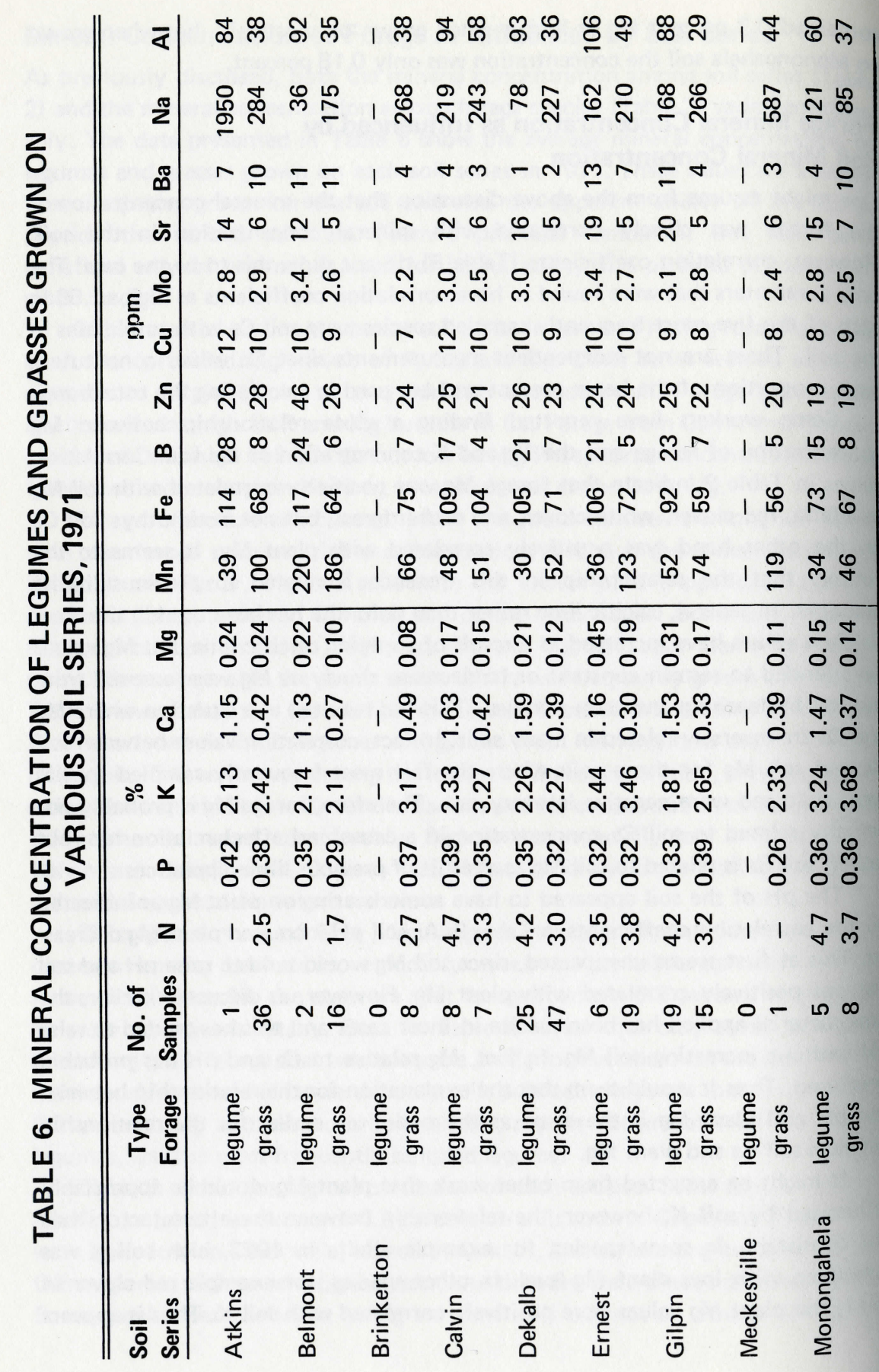

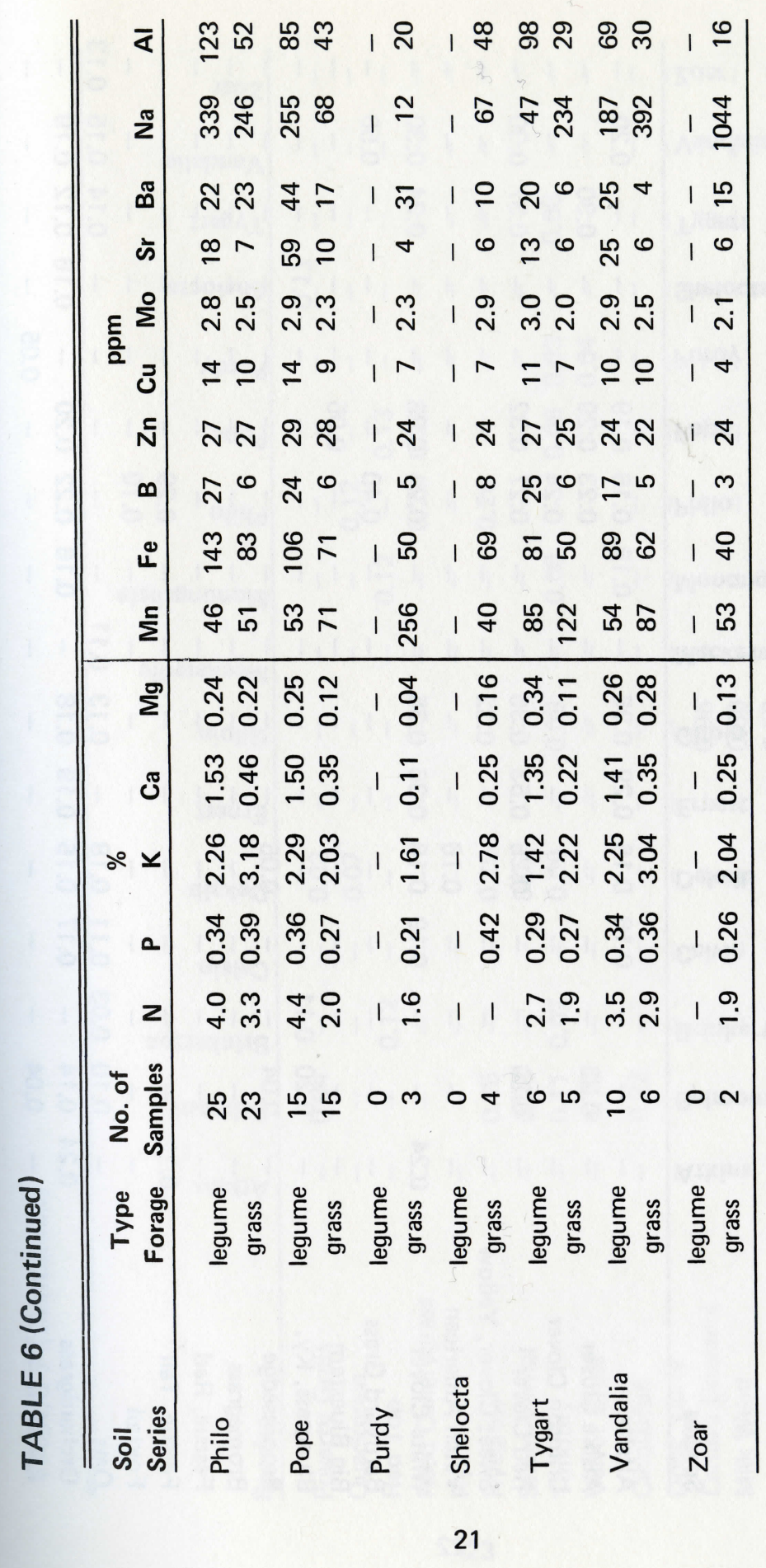



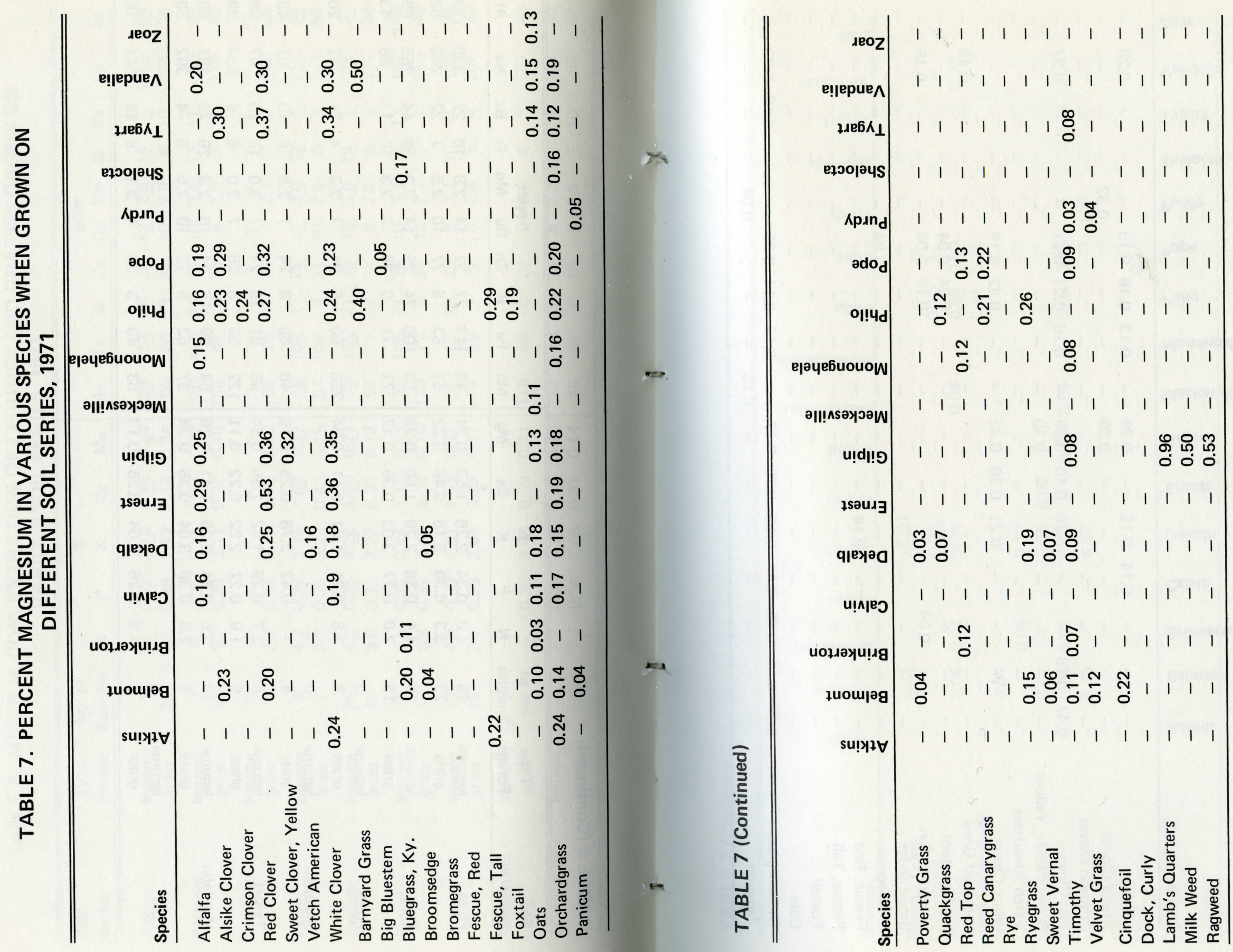
TABLE 8. CORRELATION COEFFICIENTS GREATER THAN .60 FOR FIVE FREQUENTLY SAMPLED SPECIES, 1971

\begin{tabular}{|c|c|c|c|c|c|}
\hline Parameters & Alfalfa & $\begin{array}{l}\text { Red } \\
\text { Clover }\end{array}$ & $\begin{array}{l}\text { White } \\
\text { Clover }\end{array}$ & $\begin{array}{c}\text { Orchard- } \\
\text { grass }\end{array}$ & Timothy \\
\hline Plant N X Plant P & +.93 & +.87 & +.75 & - & +.72 \\
\hline Plant N X Plant K & +.68 & - & +.82 & +.66 & +.69 \\
\hline Plant N X Plant Ca & - & - & -.67 & - & +.88 \\
\hline Plant N X Plant Mg & - & - & -.79 & - & +.77 \\
\hline Plant N X Plant Mn & - & - & -.72 & - & - \\
\hline Plant N X Plant Fe & - & +.77 & - & +.64 & +.81 \\
\hline Plant N X Plant B & - & - & - & - & +.76 \\
\hline Plant N X Plant Zn & - & - & +.82 & - & - \\
\hline Plant N X Plant Cu & - & - & +.61 & +.62 & +.90 \\
\hline Plant N X Plant Mo & - & - & -.65 & - & - \\
\hline Plant N X Plant Sr & - & - & - & - & +.65 \\
\hline Plant $\mathrm{N} \times$ Soil $\mathrm{pH}$ & - & +.69 & +.71 & - & +.67 \\
\hline Plant N X Soil Ca & - & - & - & - & +.80 \\
\hline Plant N X Soil K & - & - & - & - & -.77 \\
\hline Plant N X Soil Zn & - & - & - & - & -.65 \\
\hline Plant N X Soil Cu & - & - & - & - & -.67 \\
\hline Plant N X Soil Bases & - & - & - & - & +.79 \\
\hline Plant P X Plant $\mathrm{K}$ & - & +.69 & - & - & +.82 \\
\hline Plant P X Plant Ca & - & - & - & - & +.63 \\
\hline Plant P X Plant Zn & +.75 & - & - & - & - \\
\hline Plant K X Plant Mg & - & - & -.60 & - & - \\
\hline Plant $\mathrm{K}$ X Plant Mn & - & - & -.66 & - & - \\
\hline Plant K X Plant Zn & - & - & +.65 & - & - \\
\hline Plant Ca X Plant Cu & - & - & - & - & +.60 \\
\hline Plant Ca X Plant Al & - & - & +.60 & - & - \\
\hline Plant Ca X Plant Sr & - & - & - & +.63 & - \\
\hline Plant Ca X Soil Bases & - & - & - & - & +.61 \\
\hline Plant Ca X Soil K & - & - & - & - & -.62 \\
\hline Plant $\mathrm{Ca}$ X Soil Ca & - & - & - & - & +.63 \\
\hline Plant $\mathrm{Mg}$ X Plant $\mathrm{Cu}$ & - & - & - & - & +.74 \\
\hline Plant Mg X Plant Mn & - & - & +.77 & - & - \\
\hline Plant Mg X Soil Mg & +.60 & +.66 & - & - & - \\
\hline Plant Mn X Plant Zn & - & +.69 & - & - & - \\
\hline Plant Mn X Soil Bases & - & -.65 & - & -.67 & - \\
\hline Plant $\mathrm{Mn} \mathrm{X}$ Soil $\mathrm{pH}$ & - & -.76 & - & -.71 & - \\
\hline Plant $\mathrm{Mn} \times$ Soil $\mathrm{Ca}$ & - & - & - & -.66 & - \\
\hline
\end{tabular}

TABLE 8 (Continued)

\begin{tabular}{|c|c|c|c|c|c|c|}
\hline Parameters & & Alfalfa & $\begin{array}{l}\text { Red } \\
\text { Clover }\end{array}$ & $\begin{array}{l}\text { White } \\
\text { Clover }\end{array}$ & $\begin{array}{l}\text { Orchard- } \\
\text { grass }\end{array}$ & Timothy \\
\hline Plant Mn X Soil Fe & & - & +.73 & - & - & - \\
\hline Plant Fe X Plant Al & & +.83 & +.70 & +.87 & - & - \\
\hline Plant B X Plant Zn & & - & +.75 & - & - & - \\
\hline Plant B X Plant Cu & & - & +.64 & - & - & - \\
\hline Plant Zn X Plant Ba & & - & +.60 & - & - & - \\
\hline Plant Zn X Soil Bases & & - & -.61 & - & - & - \\
\hline Plant Zn X Soil P & & - & -.60 & - & - & - \\
\hline Plant $\mathrm{Zn} \times$ Soil Fe & & - & +62 & - & - & - \\
\hline Plant Cu X Plant Al & & - & - & - & - & +.71 \\
\hline Plant Sr X Plant Ba & & +.88 & +.67 & +.79 & - & - \\
\hline Plant Sr X Plant $\mathrm{Na}$ & $\cdot$ & +.76 & - & - & - & - \\
\hline Plant Sr X Soil Mn & & +.78 & +.85 & +.78 & - & +.64 \\
\hline Plant Ba X Plant $\mathrm{Na}$ & & +.67 & - & - & - & - \\
\hline Plant Ba X Soil Mn & & +.72 & +.72 & +.75 & - & +.68 \\
\hline Plant Ba X Soil Zn & & +.64 & - & - & - & - \\
\hline Soil pH X Soil Ca & & - & - & +.68 & +.78 & +.90 \\
\hline Soil $\mathrm{pH} \times$ Soil $\mathrm{Mg}$ & & - & - & -.73 & - & . - \\
\hline Soil pH X Soil Bases & & - & +.74 & +.63 & +.79 & - \\
\hline Soil pH X Soil $\mathrm{Cu}$ & & - & - & - & - & -.63 \\
\hline Soil pH X Soil Fe & & -.78 & -.69 & - & -.84 & -.76 \\
\hline Soil O.M. X Soil P & & - & +.82 & +.83 & +.68 & - \\
\hline Soil O. M. X Soil Ca & & - & +.78 & +.79 & +.69 & - \\
\hline $\begin{array}{l}\text { Soil O. M. X Soil Mg } \\
\text { Soil O.M. X Soil Bases }\end{array}$ & & - & $+\overline{78}$ & $+\overline{82}$ & $+\overline{70}$ & $\begin{array}{l}-.61 \\
-\end{array}$ \\
\hline Soil $\mathrm{P} \times$ Soil $\mathrm{K}$ & & - & - & +.72 & - & - \\
\hline Soil P X Soil Ca & & +.62 & +.74 & - & +.80 & - \\
\hline Soil P X Soil Bases & & +.66 & +.78 & - & +.81 & - \\
\hline Soil K X Soil Ca & & +.63 & - & - & - & - \\
\hline Soil $\mathrm{K} \times$ Soil Bases & & +.68 & - & - & - & - \\
\hline Soil K X Soil Zn & & - & - & +.62 & - & - \\
\hline Soil Ca X Soil Bases & & +.99 & +.99 & +.99 & +.99 & +.91 \\
\hline Soil Mg X Soil Zn & & +.72 & - & +.63 & - & - \\
\hline Soil Bases $X$ Soil Fe & & - & - & - & - & -.63 \\
\hline Soil $\mathrm{Zn} \times$ Soil Fe & & - & - & +.60 & - & - \\
\hline Soil $\mathrm{Mn} \times$ Soil $\mathrm{Cu}$ & & - & - & - & - & +.61 \\
\hline Soil $\mathrm{Mn} \times$ Soil Fe & & - & - & +.60 & - & - \\
\hline Soil $\mathrm{Cu} \times$ Soil Fe & & - & - & - & - & +71 \\
\hline
\end{tabular}




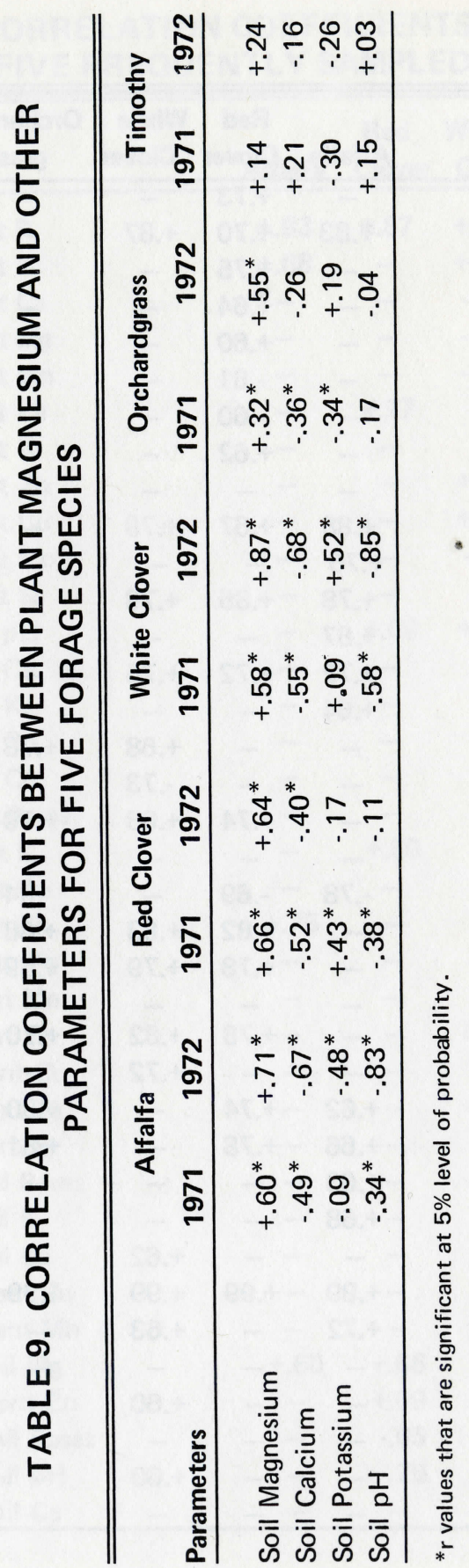

that the association between soil $\mathrm{K}$ and plant $\mathrm{Mg}$ varies among species and also years.

Timothy, in contrast to the other four species in Table 9, did not seem to vary in $\mathrm{Mg}$ concentration in the same way as the other species. Changing soil nutrient levels had little or no effect on plant Mg. Considerable difference may therefore exist among species with regard to how much forage mineral concentration can be determined by soil amendments. Timothy would appear to be a poor choice and alfalfa a better one when attempting to change forage $\mathrm{Mg}$ concentration by soil treatment.

\section{Forage Mineral Concentration as Influenced by Maturity}

Maturity had considerable influence on the concentration of several minerals in the species studied (Figures 2-9 and Appendix Table 4). Nitrogen concentration decreased rapidly from the vegetative growth stage until seeds were evident. Figures 2 through 9 show the change in $\mathrm{P}, \mathrm{K}, \mathrm{Ca}$, and $\mathrm{Mg}$ in the legumes and grasses which were sampled most frequently. In the legumes, $\mathrm{P}$ and $\mathrm{K}$ decreased rapidly from vegetative growth to seed stage. Calcium and $\mathrm{Mg}$ increased slightly in legumes from the vegetative growth stage until bloom, then decreased. In the grasses, $\mathrm{P}$ and $\mathrm{K}$ concentrations followed a trend similar to that observed in the legumes. Magnesium and $\mathrm{Ca}$ concentrations remained nearly constant or increased slightly from the vegetative to the full-bloom stage and then decreased.

In orchardgrass, tall fescue, reed canarygrass, and Kentucky bluegrass, vegetative regrowth was higher in $\mathrm{Mg}$ concentration than forage at any other stage. The regrowth of timothy, ryegrass, and quackgrass was not appreciably higher in $\mathrm{Mg}$ than other stages of growth. In timothy the vegetative regrowth was actually lower in $\mathrm{Mg}$ than forage at earlier growth stages.

The micronutrients were not affected by advancing maturity as much as were the macronutrients. With $\mathrm{Mn}, \mathrm{Fe}$, and Mo little or no trend was evident. Boron, $\mathrm{Cu}$, and $\mathrm{Zn}$ in grasses had a slight tendency to decrease as maturity advanced, whereas these elements remained constant in legumes throughout the year. Sodium increased in all species as maturity advanced; however, the concentration of this element in the forage was found to be low and quite variable.

\section{Mineral Concentration of Forages as Influenced}

\section{by Climatic Conditions}

All sites where forage samples were collected in 1971-72 were placed into one of four groups according to climatic conditions. Table 1 shows the temperature and moisture conditions in each region. A section describing the weather conditions in each area is included as part of the experimental procedure. 


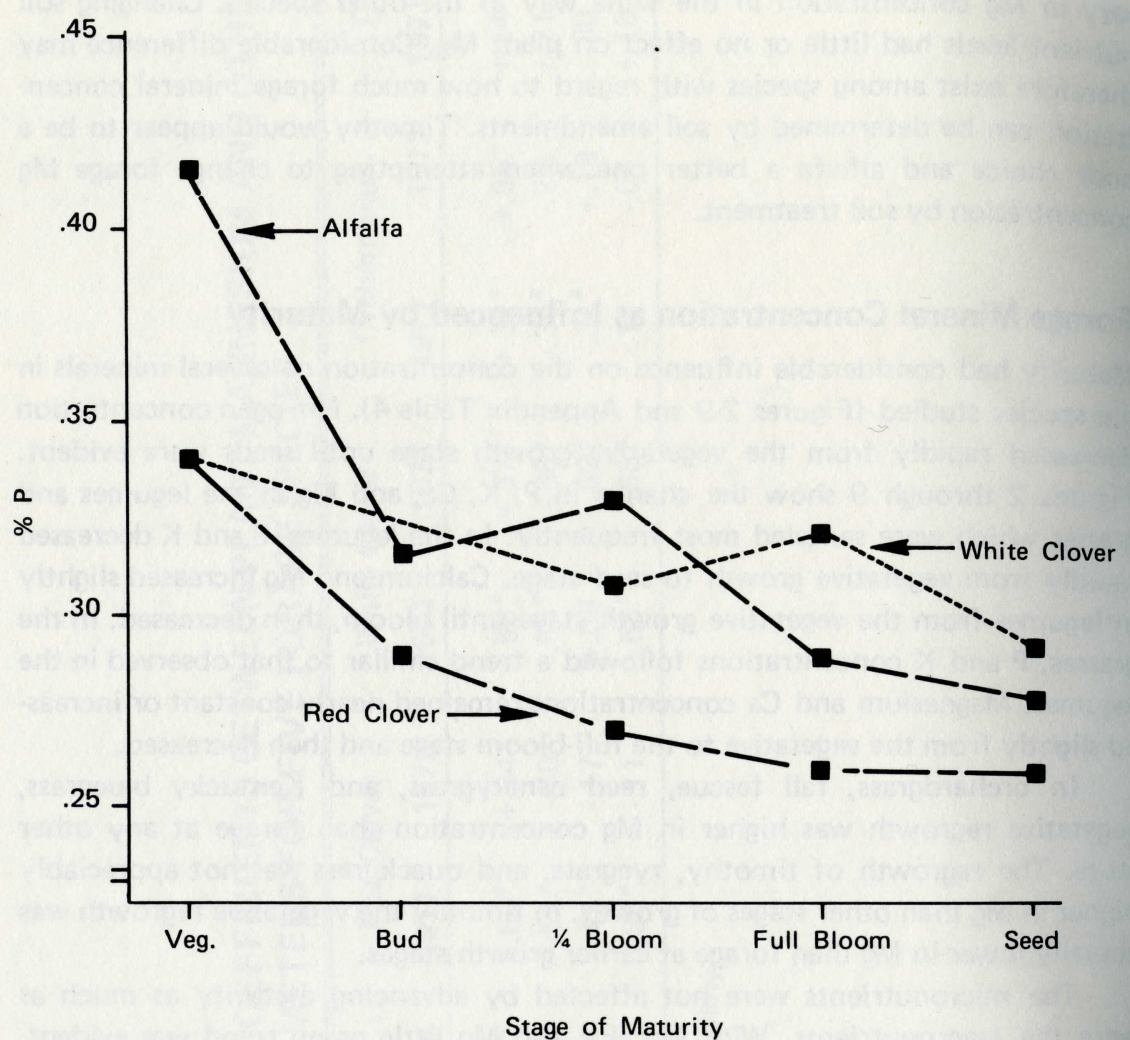

Figure 2. Percent $P$ in three legumes at various stages of maturity, 1971 and 1972 combined.

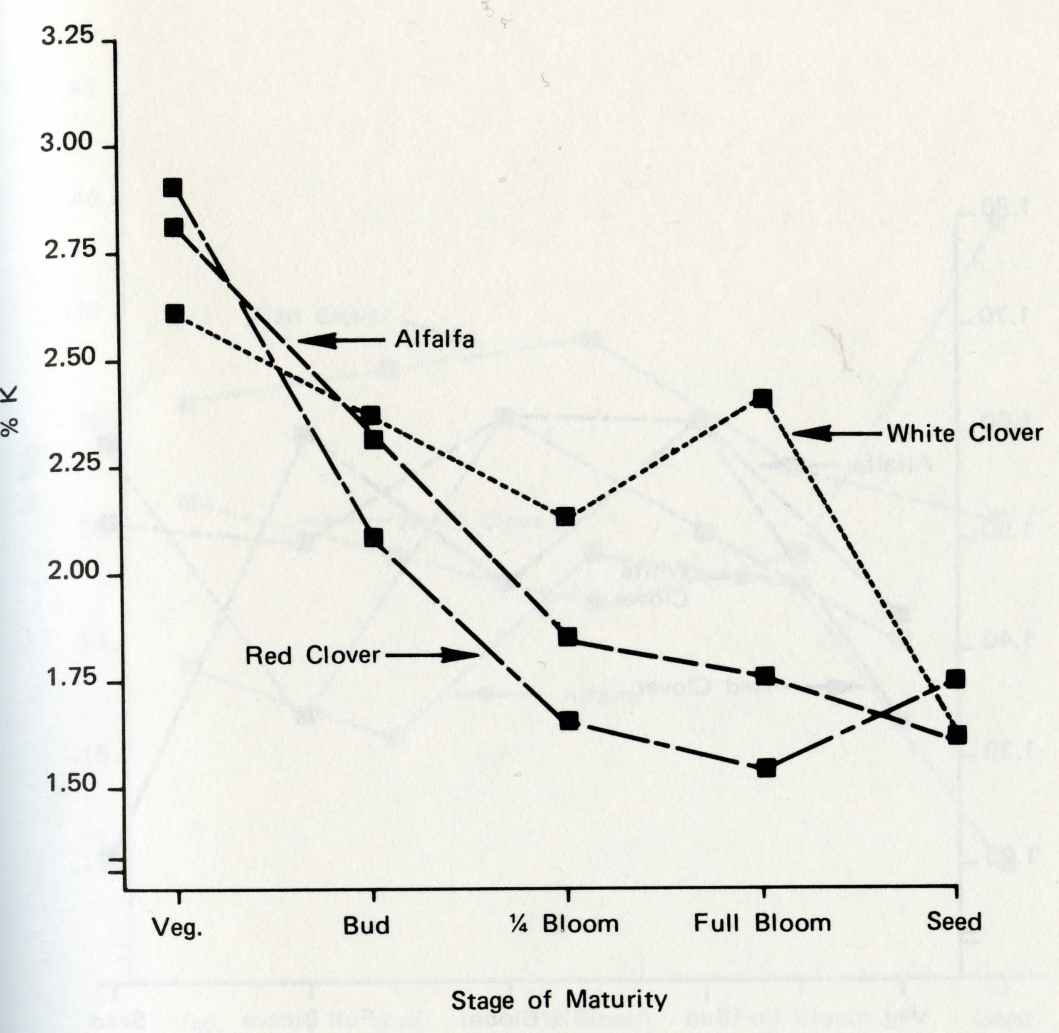

Figure 3. Percent $K$ in three legumes at various stages of maturity, 1971 and 1972 combined. 


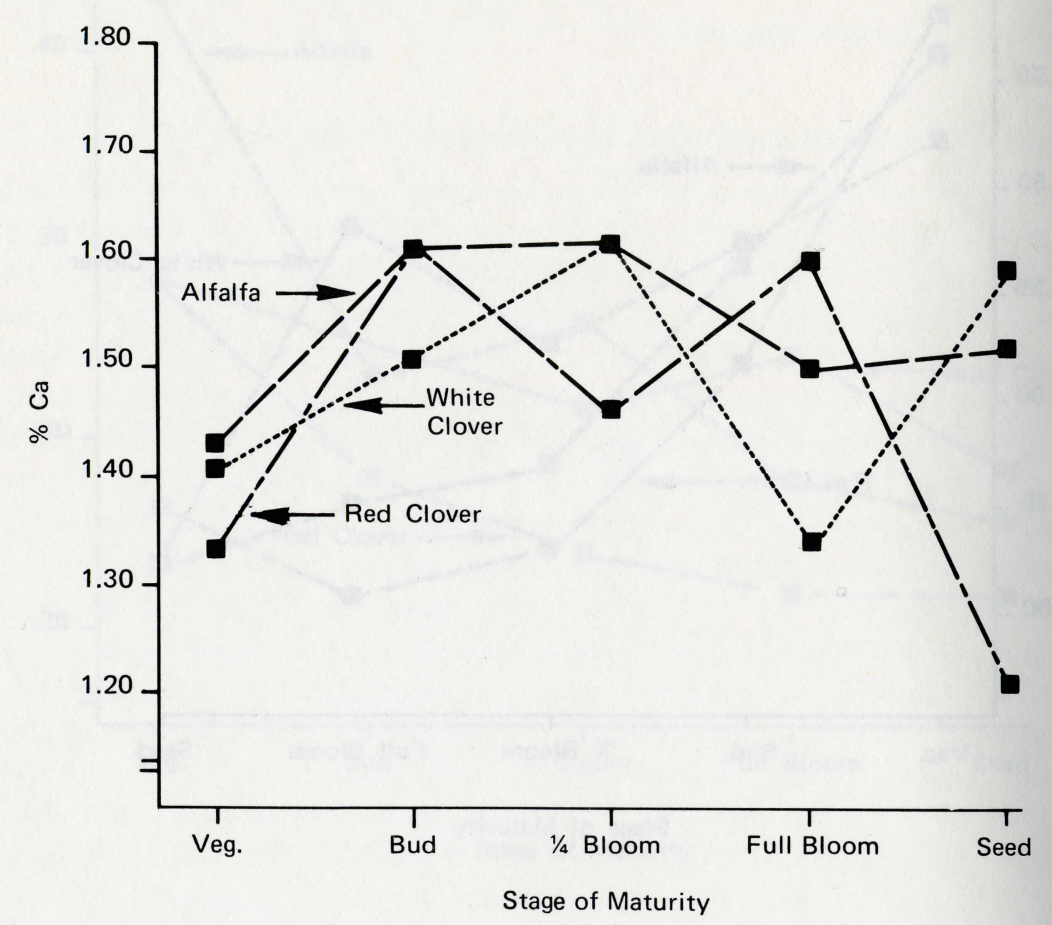

Figure 4. Percent $\mathrm{Ca}$ in three legumes at various stages of maturity, 1971 and 1972 combined.

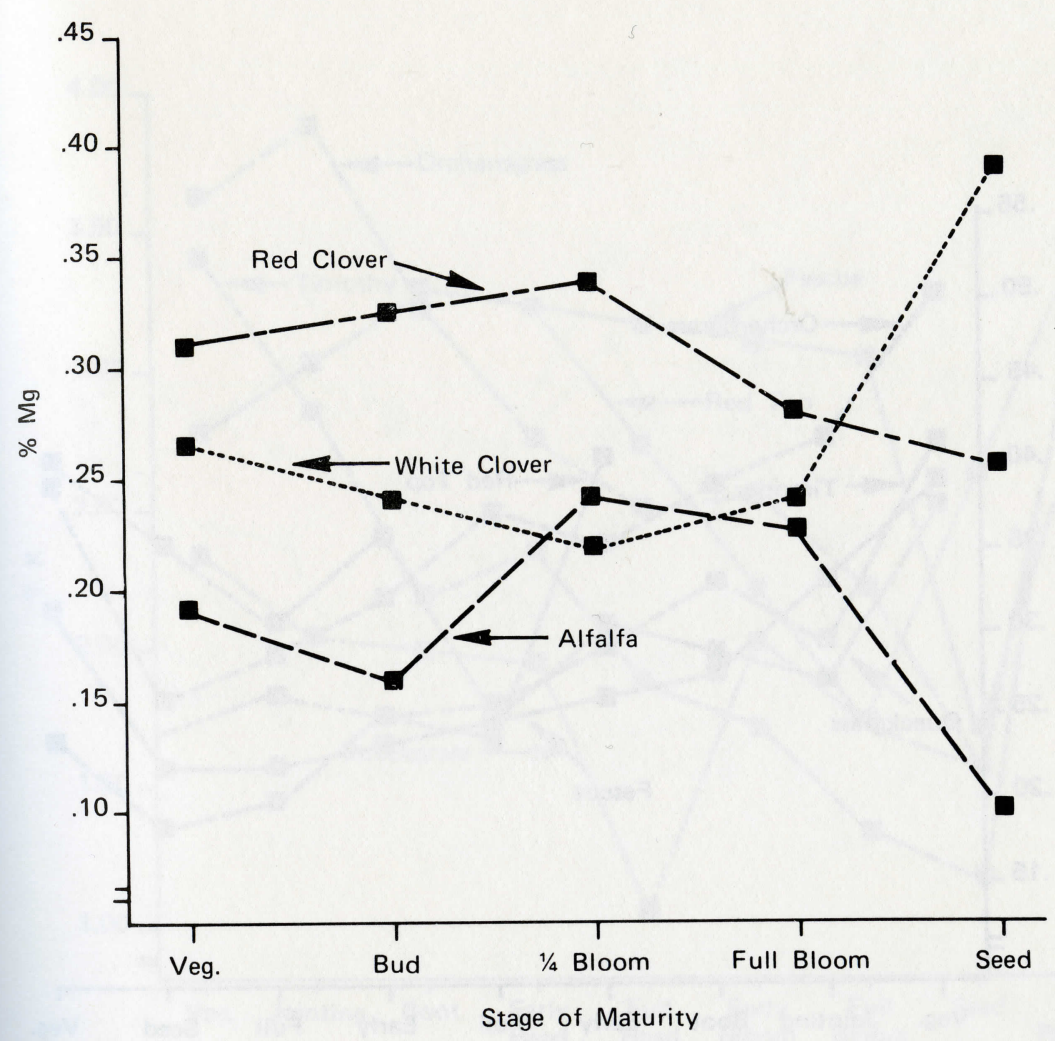

Figure 5. Percent $\mathrm{Mg}$ in three legumes at various stages of maturity, 1971 and 1972 combined. 


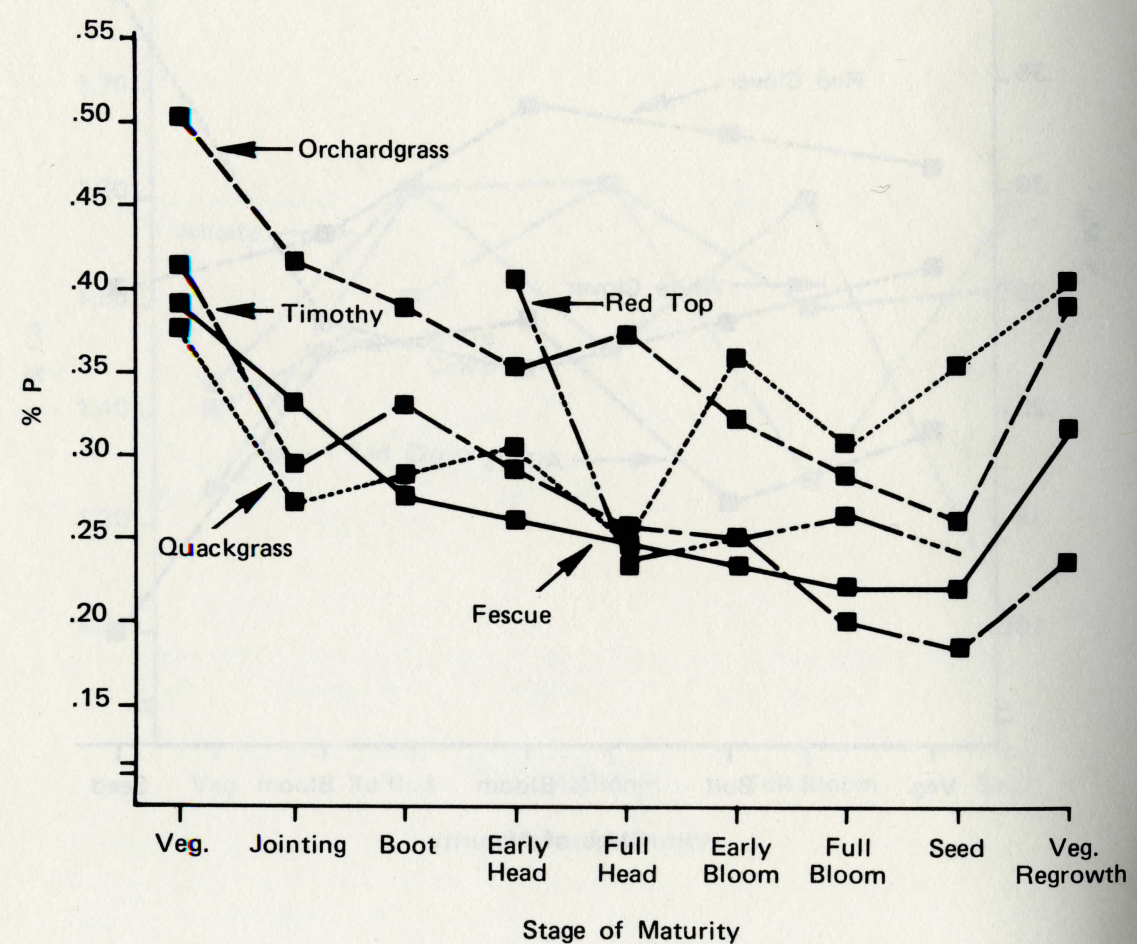

Figure 6. Percent $P$ in five grasses at various stages of maturity, 1971 and 1972 combined.

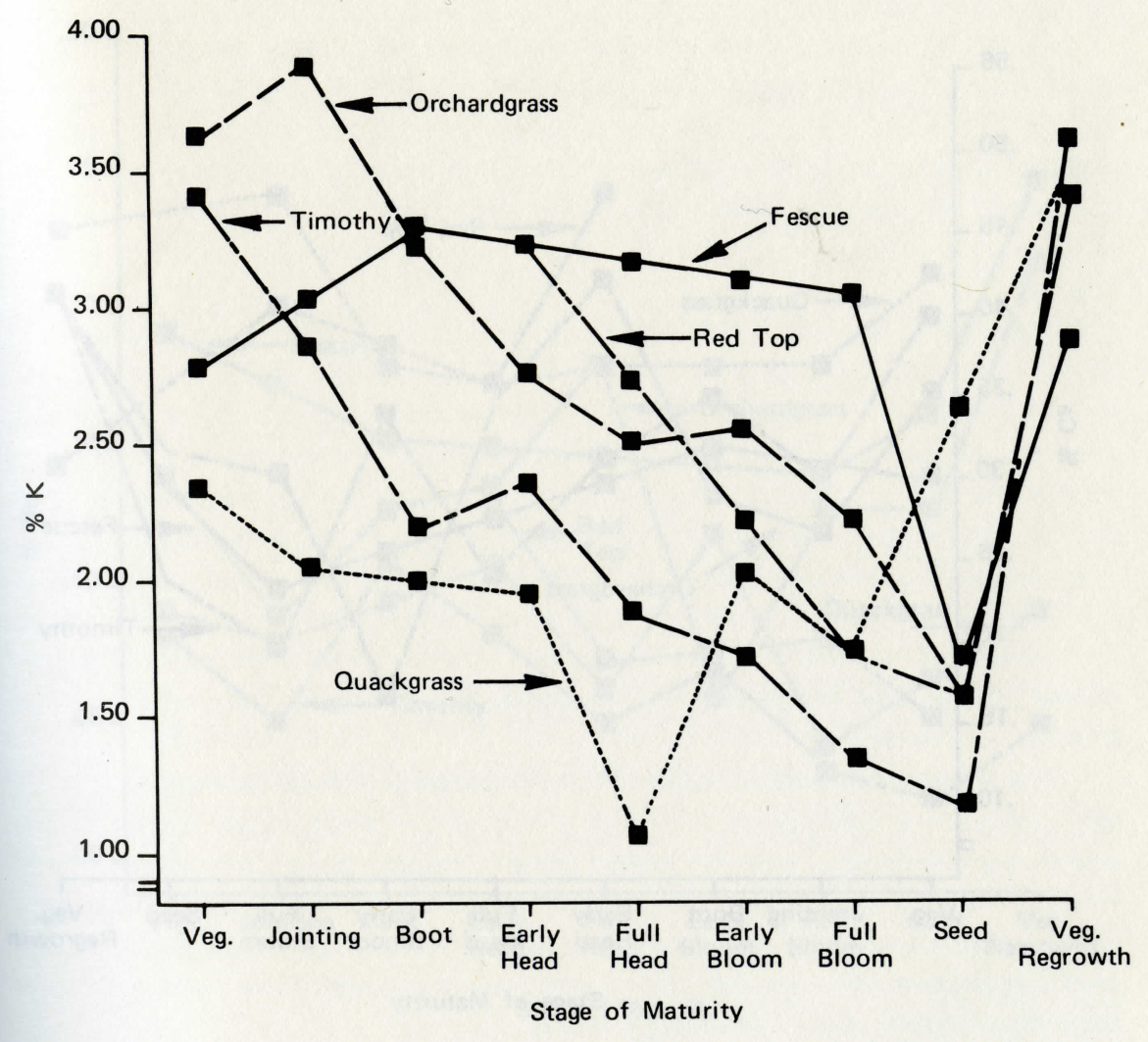

Figure 7. Percent $K$ in five grasses at various stages of maturity, 1971 and 1972 combined. 


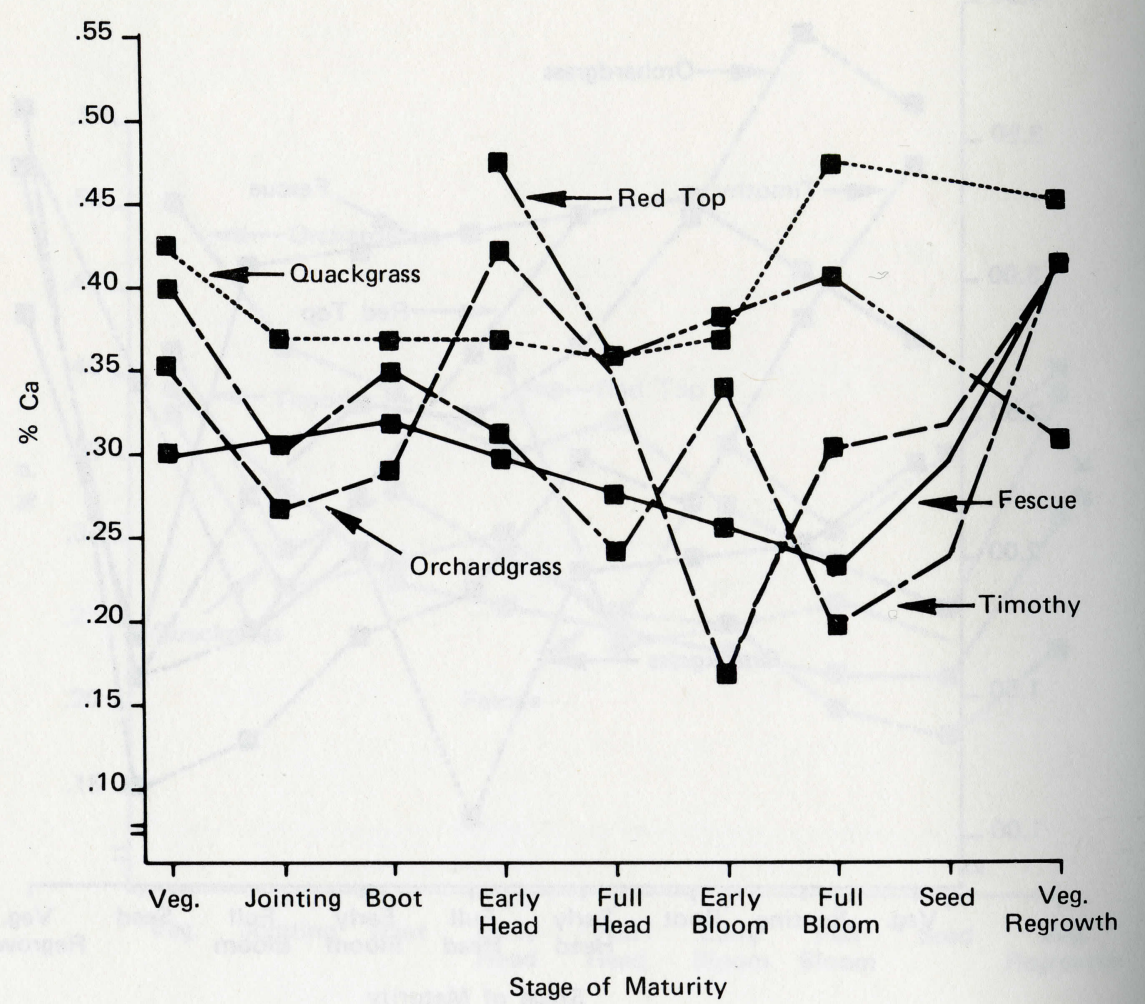

Figure 8. Percent Ca in five grasses at various stages of maturity, 1971 and 1972 combined.

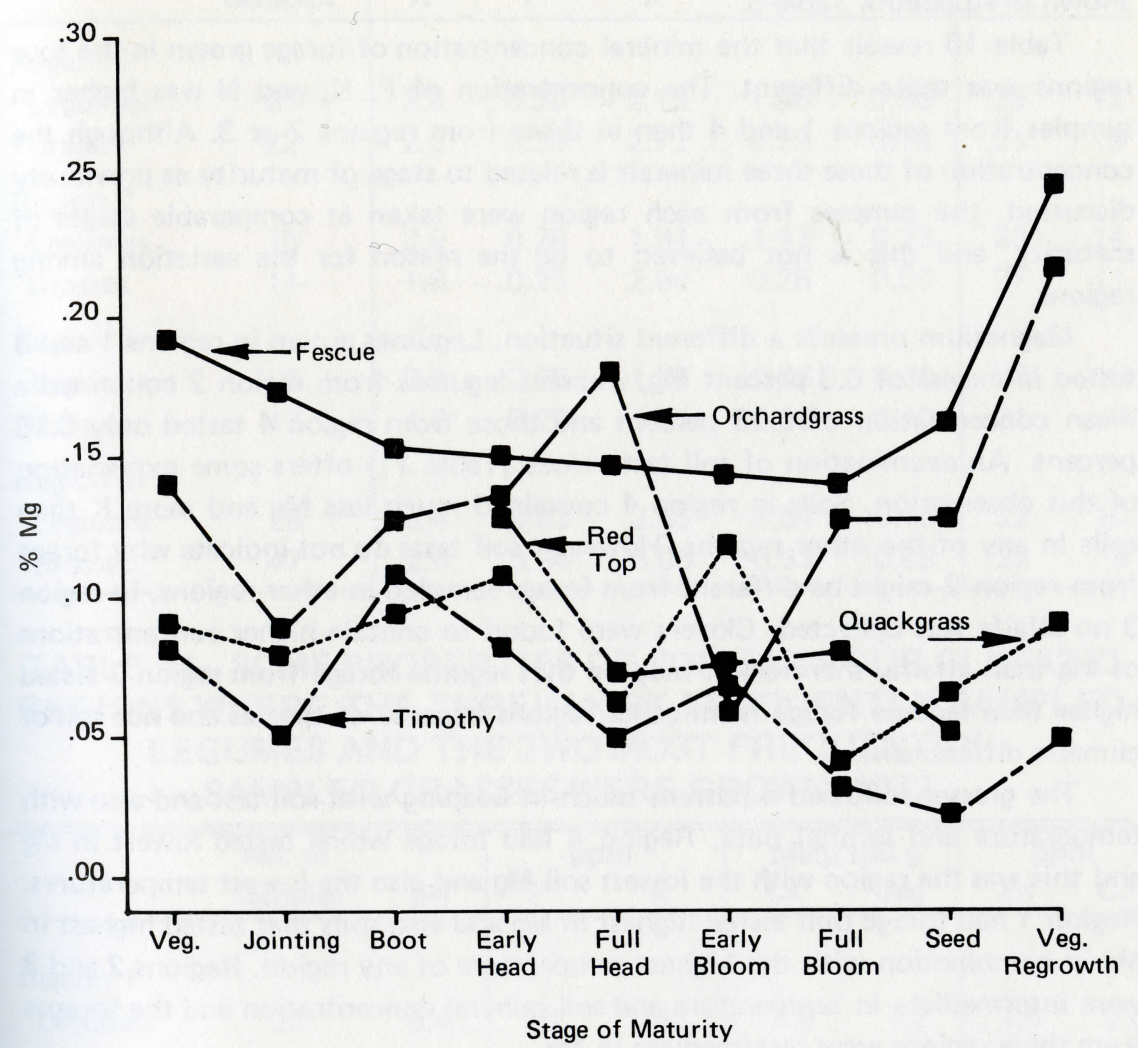

Figure 9. Percent Mg in five grasses at various stages of maturity, 1971 and 1972 combined. 
Since weather conditions were different among the four regions one might expect to find different soils. This was the case and there were no soil series common to all regions. Dekalb and Pope series were the only two which occurred in more than one area. Although soil variations existed, it was believed to be worthwhile to look at the mineral concentration of forages from different soils within each of the regions. Data for the five most frequently sampled species are shown in Appendix Table 5.

Table 10 reveals that the mineral concentration of forage grown in the four regions was quite different. The concentration of $P, K$, and $N$ was higher in samples from regions 1 and 4 than in those from regions 2 or 3 . Although the concentration of these three minerals is related to stage of maturity as previously discussed, the samples from each region were taken at comparable stages of maturity, and this is not believed to be the reason for the variation among regions.

Magnesium presents a different situation. Legumes grown in regions 1 and 3 tested in excess of 0.3 percent $\mathrm{Mg}$, whereas legumes from region 2 contained a mean concentration of 0.23 percent and those from region 4 tested only 0.16 percent. An examination of soil test values (Table 11) offers some explanation of this observation. Soils in region 4 contained much less $\mathrm{Mg}$ and more $\mathrm{K}$ than soils in any of the other regions. However, soil tests do not indicate why forage from region 2 might be different from forage sampled in other regions. In region 3 no alfalfa was collected. Clovers were found to contain higher concentrations of $\mathrm{Mg}$ than alfalfa, therefore it may be that legume forage from region 3 tested higher than legume forage from other regions because of species and not soil or climatic differences.

The grasses followed a pattern much in keeping with soil test and also with temperature and rainfall data. Region 4 had forage which tested lowest in $\mathrm{Mg}$ and this was the region with the lowest soil $\mathrm{Mg}$ and also the lowest temperatures. Region 1 had forage that tested highest in $\mathrm{Mg}$ and also soils that tested highest in $\mathrm{Mg}$ in combination with the highest temperature of any region. Regions 2 and 3 were intermediate in temperature and soil mineral concentration and the forages from these regions were intermediate in $\mathrm{Mg}$.

\section{Forage Mineral Concentration as Influenced by Year}

In general the mineral concentrations of forages were similar for the two years. Nitrogen, however, was much lower in 1972 than in 1971 in all legumes. Nitrogen was lower in several of the grasses in 1972 than in 1971, but most noticeably in orchardgrass, where the percent nitrogen dropped from 3.6 to 2.2 (Table 3). This was probably due to two factors. In 1971 four sampling sites with nearly pure orchardgrass stands were fertilized with $\mathrm{N}$. These sites were not fertilized with $\mathrm{N}$ in 1972. In addition to the effect of $\mathrm{N}$, more aftermath samples of orchardgrass were taken in 1971 than in 1972 and the $\mathrm{N}$ concentration was
TABLE 10. AVERAGE MINERAL CONCENTRATION OF THE THREE MOST FREQUENTLY SAMPLED LEGUMES AND THE TWO MOST FREQUENTLY SAMPLED GRASSES FOR FOUR CLIMATIC REGIONS, 1972.

\begin{tabular}{|c|c|c|c|c|c|c|c|c|}
\hline \multirow{2}{*}{\multicolumn{2}{|c|}{$\begin{array}{c}\text { No. of } \\
\text { Samples }\end{array}$}} & \multirow[b]{2}{*}{$\mathbf{N}$} & \multirow[b]{2}{*}{$\mathbf{P}$} & \multirow{2}{*}{$\begin{array}{l}\% \\
\mathbf{K}\end{array}$} & \multirow[b]{2}{*}{$\mathrm{Ca}$} & \multirow[b]{2}{*}{$\mathrm{Mg}$} & \multicolumn{2}{|c|}{ ppm } \\
\hline & & & & & & & $\mathrm{Zn}$ & $\mathrm{Cu}$ \\
\hline \multicolumn{9}{|l|}{ Region 1} \\
\hline Legumes & 25 & 3.3 & 0.30 & 2.16 & 1.36 & 0.36 & 25 & 12 \\
\hline Grasses & 22 & 2.2 & 0.35 & 2.72 & 0.29 & 0.18 & 21 & 9 \\
\hline \multicolumn{9}{|l|}{ Region 2} \\
\hline Legumes & 15 & 2.9 & 0.28 & 1.94 & 1.43 & 0.23 & 23 & 14 \\
\hline Grasses & 14 & 1.6 & 0.25 & 2.04 & 0.25 & 0.09 & 27 & 11 \\
\hline \multicolumn{9}{|l|}{ Region 3} \\
\hline Legumes & 5 & 2.8 & 0.25 & 1.25 & 2.05 & 0.31 & 23 & 10 \\
\hline Grasses & 12 & 1.6 & 0.29 & 1.74 & 0.38 & 0.10 & 21 & 9 \\
\hline \multicolumn{9}{|l|}{ Region 4} \\
\hline Legumes & 28 & 3.4 & 0.33 & 2.65 & 1.54 & 0.16 & 22 & 10 \\
\hline Grasses & 47 & 20 & 0.34 & 3.06 & 0.33 & 0.08 & 22 & 9 \\
\hline
\end{tabular}

TABLE 11. SOME PROPERTIES OF SOILS IN FOUR CLIMATIC REGIONS WHERE THE THREE MOST FREQUENTLY SAMPLED LEGUMES AND THE TWO MOST FREQUENTLY SAMPLED GRASSES WERE GROWN, 1972.

\begin{tabular}{|c|c|c|c|c|c|c|c|c|}
\hline & \multirow{2}{*}{$\begin{array}{l}\text { No. of } \\
\text { Samples }\end{array}$} & \multirow[b]{2}{*}{$\mathrm{pH}$} & \multicolumn{2}{|c|}{ ppm } & \multicolumn{2}{|c|}{$\mathrm{Meq} / 100 \mathrm{~g}$} & \multicolumn{2}{|c|}{ ppm } \\
\hline & & & $\mathbf{P}$ & K & $\mathrm{Ca}$ & $\mathrm{Mg}$ & $\mathrm{Zn}$ & $\mathrm{Cu}$ \\
\hline \multicolumn{9}{|l|}{ Region 1} \\
\hline Legumes & 25 & 6.4 & 18 & 143 & 5.9 & 1.7 & 1.0 & 0.6 \\
\hline Grasses & 22 & 6.4 & 18 & 144 & 5.8 & 1.7 & 1.0 & 0.7 \\
\hline \multicolumn{9}{|l|}{ Region 2} \\
\hline Legumes & 15 & 6.5 & 15 & 119 & 8.0 & 1.3 & 1.0 & 4.3 \\
\hline Grasses & 14 & 6.3 & 19 & 131 & 7.2 & 1.3 & 0.9 & 3.3 \\
\hline \multicolumn{9}{|l|}{ Region 3} \\
\hline Legumes & 5 & 6.7 & 43 & 138 & 18.2 & 1.2 & 1.8 & 0.9 \\
\hline Grasses & 12 & 6.5 & 36 & 125 & 15.2 & 1.1 & 1.5 & 0.7 \\
\hline \multicolumn{9}{|l|}{ Region 4} \\
\hline Legumes & 28 & 6.9 & 28 & 157. & 16.7 & 0.7 & 0.9 & 0.6 \\
\hline Grasses & 47 & 6.3 & 22 & 133 & 11.8 & 0.8 & 1.3 & 0.7 \\
\hline
\end{tabular}


higher in aftermath samples as previously discussed. The difference in $\mathrm{N}$ concentration in legume samples between years is not understood since none of the sites with legumes received $\mathrm{N}$ and there was no appreciable difference in the number of samples taken at various stages of maturity during the two years.

Every legume and grass species sampled had a lower Mo concentration in the 1972 samples than in the 1971 samples. Other workers have found Mo variation to be considerable among years (23). Although there were variations in mineral concentration between years, when all legumes were combined the average concentration of minerals other than $\mathrm{N}$ and Mo were very similar in both years. The mineral concentrations of the combined grass species were also very similar for the two years, except for $\mathrm{N}$ and Mo.

\section{CONCLUSIONS}

Results indicate that several factors are important in determining the mineral concentration of forage being consumed by livestock in central West Virginia. The most important factor affecting mineral concentration in this investigation was plant species. Variation among species for a particular mineral was as high as 1,000 -fold in some cases. In general, the variation among species was much less, although variations of 2- to 10-fold were observed frequently. The weed species contained higher concentrations of $\mathrm{P}, \mathrm{K}, \mathrm{Mg}, \mathrm{Mn}, \mathrm{Fe}, \mathrm{B}, \mathrm{Zn}, \mathrm{Cu}, \mathrm{Mo}, \mathrm{Sr}, \mathrm{Ba}$, and $\mathrm{Al}$ than either legumes or grasses. Legumes were the group highest in $\mathrm{Ca}$ concentration, and contained higher levels of $\mathrm{N}, \mathrm{Mg}, \mathrm{Fe}, \mathrm{B}, \mathrm{Zn}, \mathrm{Cu}, \mathrm{Mo}, \mathrm{Sr}, \mathrm{Ba}$, and Al than the grasses.

Most forage consumed by livestock in pastures is a mixture of species, with as many as four to six species frequently making up appreciable amounts of the available forages. From the standpoint of mineral nutrition of livestock it would seem that a mixture of species is desirable, since no single species or family was consistently high in all essential minerals. Although the weeds tended to be high in mineral concentration, palatability of this group is usually comparatively low. From a practical viewpoint, some weeds in association with pasture legumes and grasses would not be undesirable as long as they are not refused by livestock.

Forage grown for hay in central West Virginia is also characterized by a mixture of species, although the number of species involved is usually less than found in pasture. Animals are likely to have limited selection in their diet when eating hay and again a mixture of species would appear to be desirable from a mineral standpoint.

The mineral concentration of soil was not found to be closely related to mineral concentration of the forage, although some positive correlations were found. The mineral concentration of soil did appear to have considerable influence in determining what species were present in swards. In general, the higher the $\mathrm{pH}, \mathrm{P}, \mathrm{K}$, and $\mathrm{Ca}$ concentration of the soil, the wider the selection of species growing at the site. In addition, legumes were more numerous on such sites.
Soil series did not appear to have a consistent effect on forage mineral concentration. However, within a given species certain soils seemed to be better at supplying particular minerals than others. In this study, forage from Atkins, Ernest, Gilpin, and Vandalia soil series was higher in $\mathrm{Mg}$ than was forage from the other soils.

The concentration of $\mathrm{N}, \mathrm{P}$, and $\mathrm{K}$ in legumes tended to decrease as the plants matured. Calcium and $\mathrm{Mg}$ on the other hand tended to increase slightly from the vegetative growth stage until bloom, and then decreased. These minerals tended to vary in a similar way in grasses, although regrowth was generally as high in mineral concentration as early vegetative growth. Other elements appeared to be more variable and trends due to maturity were not consistent.

Forage mineral concentrations were not the same for forages grown in different climatic regions. There was also some variation in mineral concentration between years.

It would seem from this study that much of the forage being produced for livestock feed in central West Virginia is deficient in one or more minerals with regard to meeting the nutritional needs of livestock. It would also appear that some species are nearly always adequate in mineral concentration, whereas others are nearly always deficient. However, since species, plant maturity, soil series, soil mineral concentration, and climatic conditions influence forage mineral concentration no single factor alone can be used to predict with certainty the mineral concentration of forage.

\section{LITERATURE CITED}

1. Allaway, W. H. 1968. "Agronomic control over the environmental cycling of trace elements." In Advances in Agronomy Vol. 20. 235-274.

2. Allaway, B. J. 1973. "Copper and molybdenum in swayback pastures." J. Agri. Sci. 80: 521-524.

3. Butler, G. W., P. C. Barclay, and A. C. Glenday, 1962. "Genetic and environmental differences in the mineral composition of ryegrass herbage." Plant and Soil 16: 214-228.

4. Cheng, B. T., S. J. Bourget, and G. J. Ouellette. 1971. “Effect of some soil physical properties on growth and manganese, iron, aluminum, and moly bdenum content of oats." Notes Can. J. Soil Sci. 51: 125-126.

5. Cooper, J. P. 1973. "Genetic variations in herbage constituents." Chapter 26 in Chemistry and Biochemistry of Herbage edited by G. W. Butler and R. W. Bailey. Vol. 2. pp. 379-417.

6. Davies, W. Ellis, T. A. Thomas, and Norman R. Young, 1967. "The assessment of herbage legume varieties. III. Annual variation in chemical composition of eight varieties." J. Agri. Sci. 71:233-241. 
7. Fleming, G. A. 1973. "Mineral composition of herbage." Chapter 12 in Chemistry and Biochemistry of Herbage edited by G. W. Butler and R. W. Bailey. Vol. 1. pp. 529-566.

8. Fleming, G. A. and W. E. Murphy. 1968. "The uptake of some major elements by grass as affected by season and stage of maturity." J. Brit. Grass. Soc. 23 (2): 174-184.

9. Gladstones, J. S. and J. F. Loneragan. 1967. “Mineral elements in temperate crop and pasture plants. I. Zinc." Aust. J. Agri. Res. 18: 427-446.

10. Griffith, G. ap and R. J. K. Walters. 1966. "The sodium and potassium content of some grass genera, species and varieties." J. Agri. Sci. 67: 81-89.

11. Hamilton, John W. and Carl S. Gilbert. 1971. "Mineral composition of native and introduced clovers." J. Range Mangement 24: 304-308.

12. Huffaker, R. C. and A. Wallace, 1958. "Possible relationships of cation exchange capacity of plant roots to cation uptake." Soil Sci. Soc. Am. Proc. 22: 392-394.

13. Jencks, Everett M. 1969. Some chemical characteristics of the major soil series of West Virginia. W.Va. Univ. Agri. Exp. Sta. Bul. 582T.

14. Jensen, E. H. and A. L. Lesperance. 1971. "Molybdenum accumulation by forage plants." Agron. J. 63: 201-204.

15. John, Matt K., G. W. Eaton, V. W. Case, and H. H. Chuah. 1972. "Liming of alfalfa (Medicago sativa L.) II. Effect on mineral composition." Plant and Soil 37: 363-374.

16. Jones, E. 1963. "Studies on the magnesium content of mixed herbage and some individual grass and clover species." J. Brit. Grass. Soc. 18: 131-138.

17. Loneragan, J. F., J. S. Gladstones, and W. J. Simmons. 1968. "Mineral elements in temperate crop and pasture plants. II. Calcium." Aust. J. Agri. Res. 19: 353-364.

18. Price, Nelson O. and W. W. Moschler. 1970. "Residual lime effect in soil on certain mineral elements in barley, fescue and oats." J. Agri. and Food Chem. 18: 5-8.

19. Reid, R. L., Amy J. Post, and G. A. Jung. 1970. Mineral Composition of Forages. W.Va. Univ. Agri. Exp. Sta. Bul. 589T.

20. Reith, J. W. S. and R. H. E. Inkson in collaboration with others. 1964. "The effect of fertilizer on herbage production. II. The effect of nitrogen, phosphorus, and potassium on botanical and chemical composition." J. Agri. Sci. 63: 209-219.

21. Scotter, George W. and J. E. Miltimore. 1973. "Mineral content of forage plants from the reindeer preserve, northwest territories." Can J. Plant Sci. 53: 263-268.

22. Stewart A. B. and W. Holmes. 1953. "Nitrogenous manuring of grassland. I. Some effects of heavy dressing of nitrogen on the mineral composition." J. Sci. Food. Agri. 4: 401-408.
23. Tingle, J. N. and W. K. Dawley. 1972. “Mineral composition of whole-plant cereals for silage in central British Columbia." Can. J. Plant Sci. 52: 805-509.

24. Todd, J. R. 1961. "Magnesium in forage plants. I. Magnesium content of different species and strains as affected by season and soil treatment." J. Agri. Sci. 56: 411-415.

25. Underwood, E. J. 1962. Trace Elements in Human and Animal Nutrition. Academic Press. New York and London. p. 368. 
APPENDIX 
APPENDIX TABLE 1. SOME PROPERTIES

OF SOIL SERIES WHERE PLANTS WERE

COLLECTED, 1971.

\begin{tabular}{|c|c|c|c|c|c|c|c|c|c|c|c|}
\hline \multirow[b]{2}{*}{ Soil Series } & \multirow[b]{2}{*}{$\mathrm{pH}$} & \multirow{2}{*}{$\begin{array}{c}\% \\
\text { O.M. }\end{array}$} & \multicolumn{2}{|c|}{ ppm } & \multicolumn{3}{|c|}{$\mathrm{meq} / 100 \mathrm{~g}$} & \multicolumn{4}{|c|}{ ppm } \\
\hline & & & $\mathbf{P}$ & K & $\mathrm{Ca}$ & $\mathrm{Mg}$ & Bases & $\mathrm{Zn}$ & Mn & $\mathrm{Cu}$ & $\mathrm{Fe}$ \\
\hline Atkins & 6.2 & 5.2 & 10 & 95 & 5.6 & 2.1 & 8.0 & 0.6 & 6 & 1.4 & 50 \\
\hline Belmont & 5.3 & 6.3 & 17 & 145 & 4.2 & 1.0 & 5.6 & 0.4 & 54 & 1.2 & 160 \\
\hline Brinkerton & 6.9 & 6.4 & 38 & 90 & 14.8 & 0.5 & 15.6 & 0.4 & 8 & 0.4 & 67 \\
\hline Calvin & 7.0 & 3.9 & 9 & 90 & 8.5 & 0.4 & 9.2 & 0.3 & 14 & 0.5 & 10 \\
\hline Dekalb & 6.4 & 7.1 & 32 & 126 & 14.9 & 0.9 & 16.2 & 1.5 & 13 & 0.7 & 77 \\
\hline Ernest & 5.9 & 4.2 & 19 & 178 & 3.6 & 1.5 & 5.6 & 1.2 & 40 & 0.8 & 71 \\
\hline Gilpin & 6.5 & 4.1 & 10 & 98 & 6.1 & 1.5 & 8.0 & 0.7 & 12 & 0.4 & 27 \\
\hline Monongahela & 7.0 & 5.4 & 19 & 220 & 21.0 & 0.6 & 22.1 & 0.3 & 17 & 0.2 & 12 \\
\hline Philo & 6.8 & 3.9 & 18 & 81 & 9.1 & 1.0 & 10.4 & 0.6 & 12 & 3.7 & 23 \\
\hline Pope & 6.6 & 5.6 & 22 & 151 & 13.7 & 1.0 & 15.1 & 1.3 & 37 & 0.9 & 69 \\
\hline Purdy & 5.2 & 7.5 & 13 & 160 & 1.6 & 0.7 & 2.7 & 2.0 & 38 & 1.7 & 200 \\
\hline Shelocta & 6.3 & 5.9 & 25 & 320 & 5.0 & 2.7 & 8.5 & 1.5 & 21 & 0.5 & 36 \\
\hline Tygart & 5.7 & 5.1 & 37 & 150 & 5.0 & 1.5 & 6.9 & 0.5 & 9 & 0.6 & 51 \\
\hline Vandalia & 6.5 & 4.5 & 24 & 120 & 9.3 & 1.7 & 11.3 & 1.2 & 17 & 1.0 & 23 \\
\hline Mean & 6.4 & 5.3 & 20 & 124 & 9.6 & 1.0 & 11.2 & 0.9 & 19 & 1.2 & 56 \\
\hline
\end{tabular}


APPENDIX TABLE 2. SOME PROPERTIES OF SOIL SERIES WHERE PLANTS WERE COLLECTED,

1972.

\begin{tabular}{|c|c|c|c|c|c|c|c|c|c|c|c|}
\hline \multirow[b]{2}{*}{ Soil Series } & \multirow[b]{2}{*}{$\mathrm{pH}$} & \multirow{2}{*}{$\begin{array}{c}\% \\
\text { O.M. }\end{array}$} & \multicolumn{2}{|c|}{ ppm } & \multicolumn{3}{|c|}{$\mathrm{meq} / 100 \mathrm{~g}$} & \multicolumn{4}{|c|}{ ppm } \\
\hline & & & $\mathbf{P}$ & K & $\mathrm{Ca}$ & $\mathrm{Mg}$ & Bases & $\mathrm{Zn}$ & Mn & $\mathrm{Cu}$ & $\mathrm{Fe}$ \\
\hline Atkins & 6.2 & 5.1 & 7 & 80 & 5.6 & 2.1 & 8.0 & 0.5 & 6 & 1.4 & 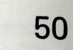 \\
\hline Belmont & 5.5 & 6.7 & 22 & 148 & 5.2 & 1.2 & 6.8 & 3.6 & 27 & 1.0 & 142 \\
\hline Brinkerton & 6.9 & 6.4 & 38 & 90 & 14.8 & 0.5 & 15.6 & 0.4 & 8 & 0.4 & 67 \\
\hline Calvin & 7.0 & 3.9 & 9 & 90 & 8.5 & 0.4 & 9.2 & 0.3 & 14 & 0.5 & 16 \\
\hline Dekalb & 6.2 & 7.1 & 27 & 125 & 13.3 & 0.8 & 14.5 & 1.6 & 15 & 0.8 & 88 \\
\hline Ernest & 6.1 & 4.4 & 29 & 246 & 3.6 & 2.2 & 6.5 & 1.4 & 20 & 0.7 & 60 \\
\hline Gilpin & 6.5 & 4.1 & 7 & 90 & 5.3 & 1.4 & 7.0 & 0.6 & 12 & 0.4 & 28 \\
\hline Monongahela & 7.0 & 5.4 & 19 & 220 & 21.0 & 0.6 & 22.1 & 0.3 & 17 & 0.2 & 12 \\
\hline Philo & 6.6 & 4.4 & 16 & 112 & 8.4 & 1.3 & 10.0 & 1.0 & 19 & 4.7 & 38 \\
\hline Pope & 6.7 & 5.6 & 23 & 149 & 13.9 & 1.0 & 15.4 & 1.3 & 37 & 0.9 & 68 \\
\hline Purdy & 5.2 & 7.5 & 13 & 160 & 1.6 & 0.7 & 2.7 & 2.0 & 38 & 1.7 & 200 \\
\hline Sheloct & 6.3 & 5.9 & 25 & 320 & 5.0 & 2.7 & 8.5 & 1.5 & 21 & 0.5 & 3 \\
\hline Tygart & 5.7 & 5.1 & 37 & 150 & 5.0 & 1.5 & 6.9 & 0.5 & 9 & 0.6 & 51 \\
\hline Vandalia & 6.5 & 4.5 & 24 & 120 & 9.3 & 1.7 & 11.3 & 1.2 & 17 & 1.0 & 23 \\
\hline Mean & 6.4 & 5.5 & 21 & 135 & 10.0 & 1.1 & 11.5 & 1.4 & 19 & 1.3 & 6 \\
\hline
\end{tabular}

APPENDIX TABLE 3.

\section{NAMES OF PLANTS COLLECTED FOR MINERAL ANALYSIS}

Common

alfalfa

alsike clover

crimson clover

red clover

sweet clover (yellow)

vetch (American)

white clover

barnyard grass

big bluestem

bluegrass (Kentucky)

broomsedge

bromegrass

fescue (red)

fescue (tall)

foxtail

oats

orchardgrass

panicum

poverty grass

quackgrass

redtop

reed canarygrass

rye

ryegrass

sweet vernal grass

timothy

velvet grass

cinquefoil

dock (curly)

lamb's quarters

milk weed

ragweed

Ambrosia artemisiifolia L.

*Scientific names taken from Flora of West Virginia by P. D. Strausbaugh and Earl L. Core. West Virginia University 1970.

\section{Scientific*}

Medicago sativa L.

Trifolium hybridum L.

Trifolium incarnatum $\mathrm{L}$.

Trifolium pratense $\mathrm{L}$.

Melilotus officinalis (L.) Lam.

Vicia americana Muhl.

Trifolium repens $\mathrm{L}$.

Echinochloa crusgalli L. Beauv.

Andropogon gerardi Vitman

Poa pratensis $\mathrm{L}$.

Andropogon virginicus $\mathrm{L}$.

Bromus japonicus Thunb.

Festuca rubra L.

Festuca arundinacea Schreb.

Setaria glauca L.

Avena sativa L.

Dactylis glomerata L.

Panicum capillare $\mathrm{L}$.

Danthonia spicata (L.) Beauv.

Agropyron repens (L.) Beauv.

Agrostis alba L.

Phalaris arundinacea $\mathrm{L}$.

Secale cereale $\mathrm{L}$.

Lolium perenne $\mathrm{L}$.

Anthoxanthum odoratum $\mathrm{L}$.

Phleum pratense $\mathrm{L}$.

Holcus lanatus L.

Potentilla simplex Michx.

Rumex crispus $\mathrm{L}$.

Chenopodium album $\mathrm{L}$.

Asclepias ayriaca L.

Ambrosia artemisiifolia L. 


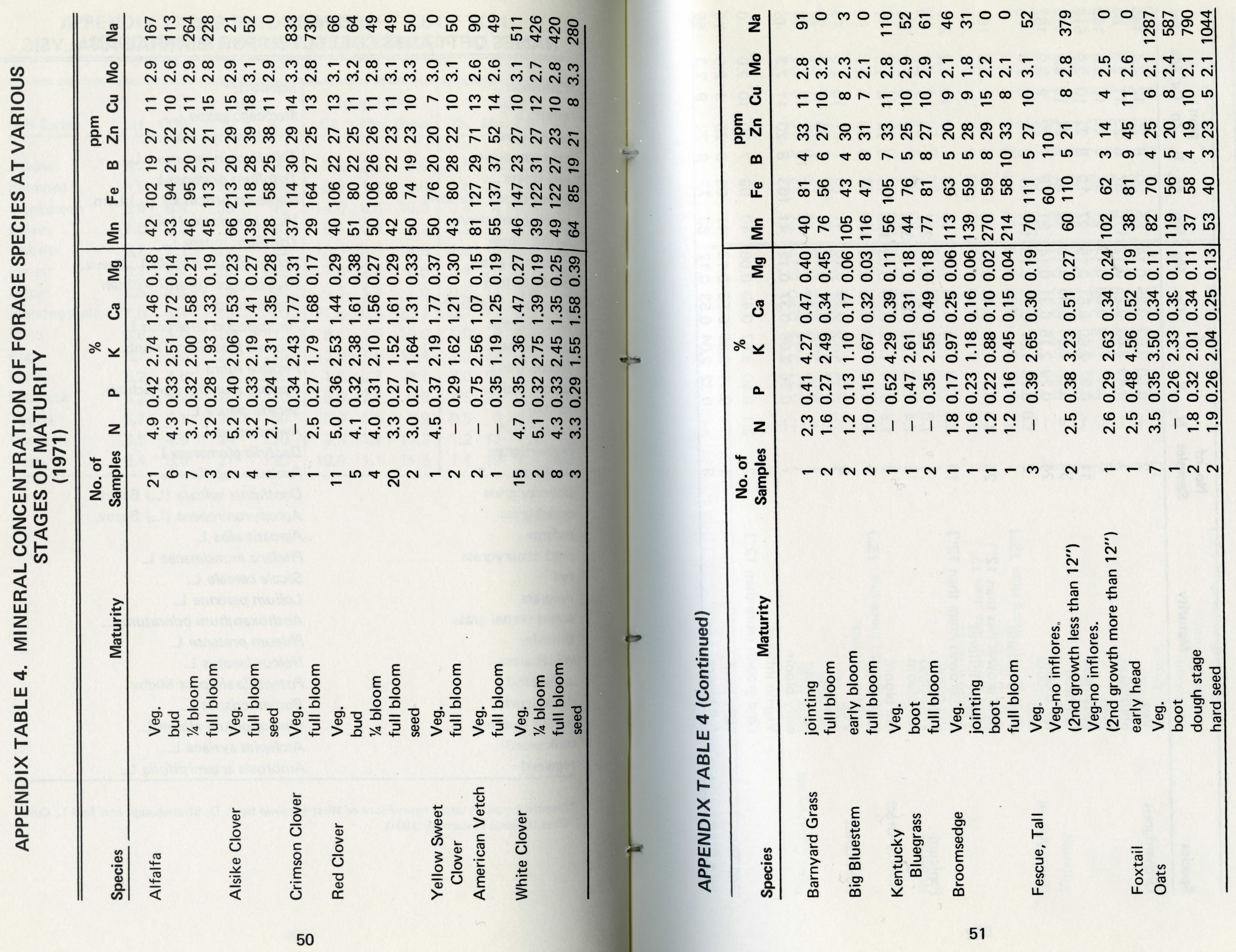




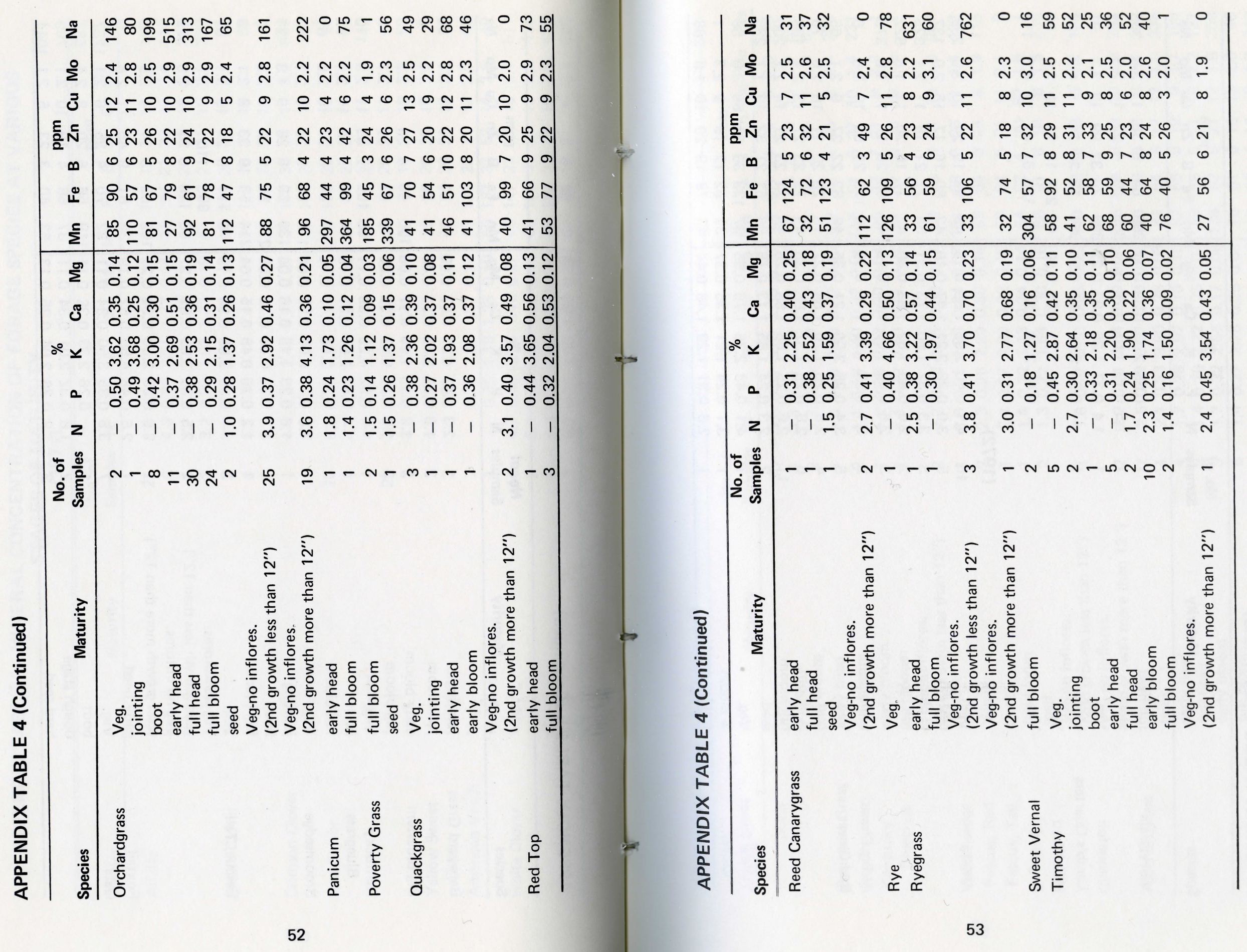



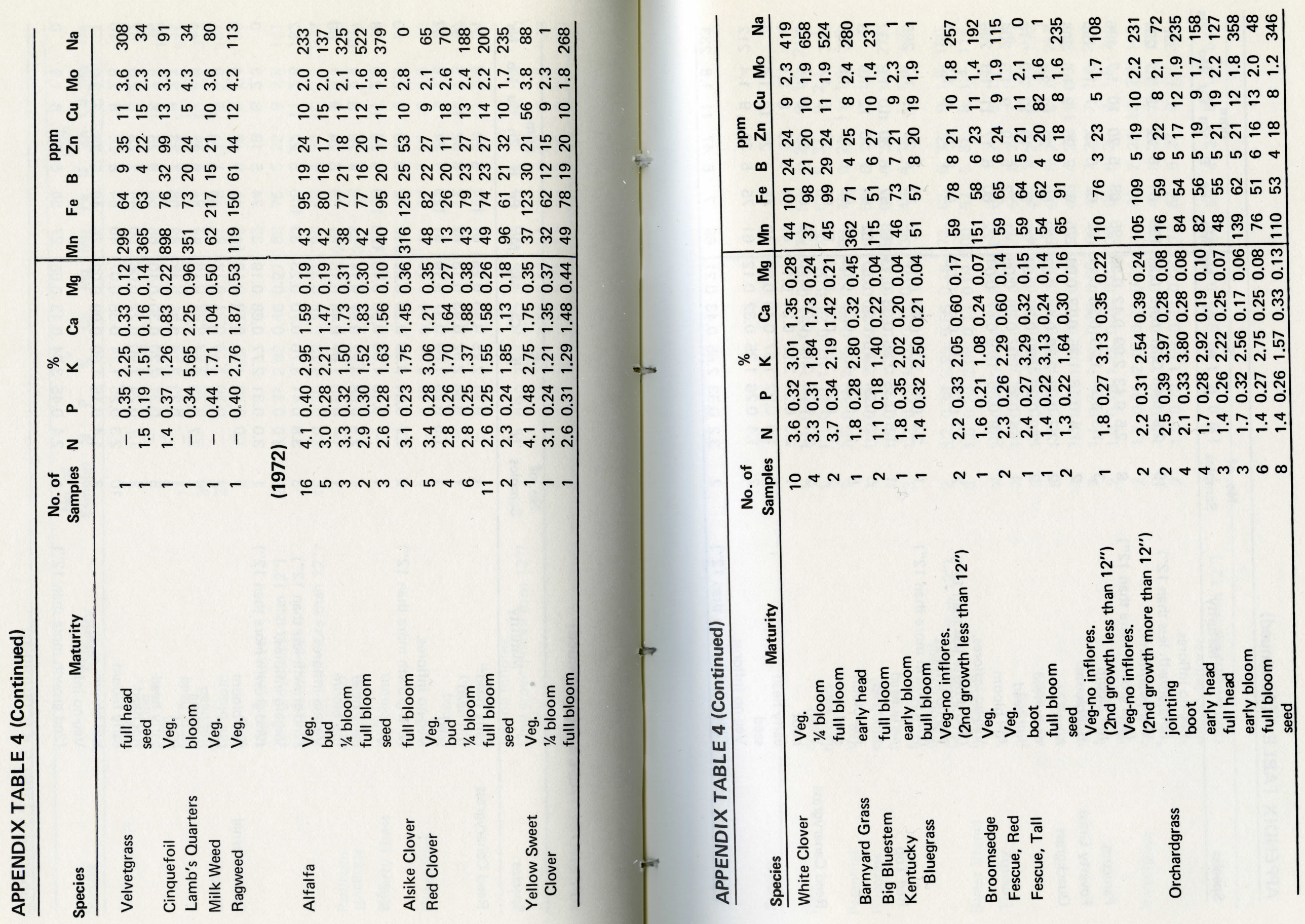


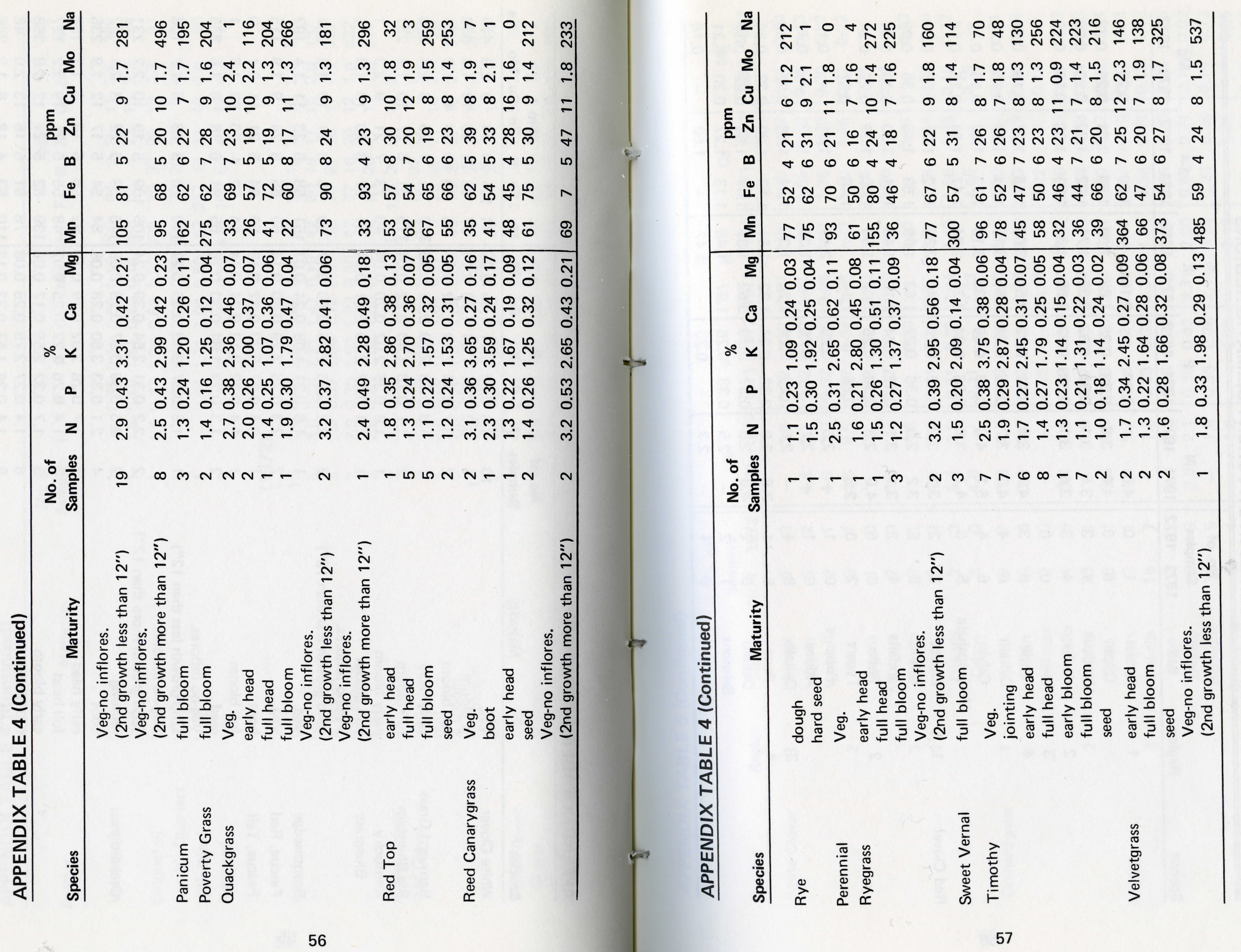




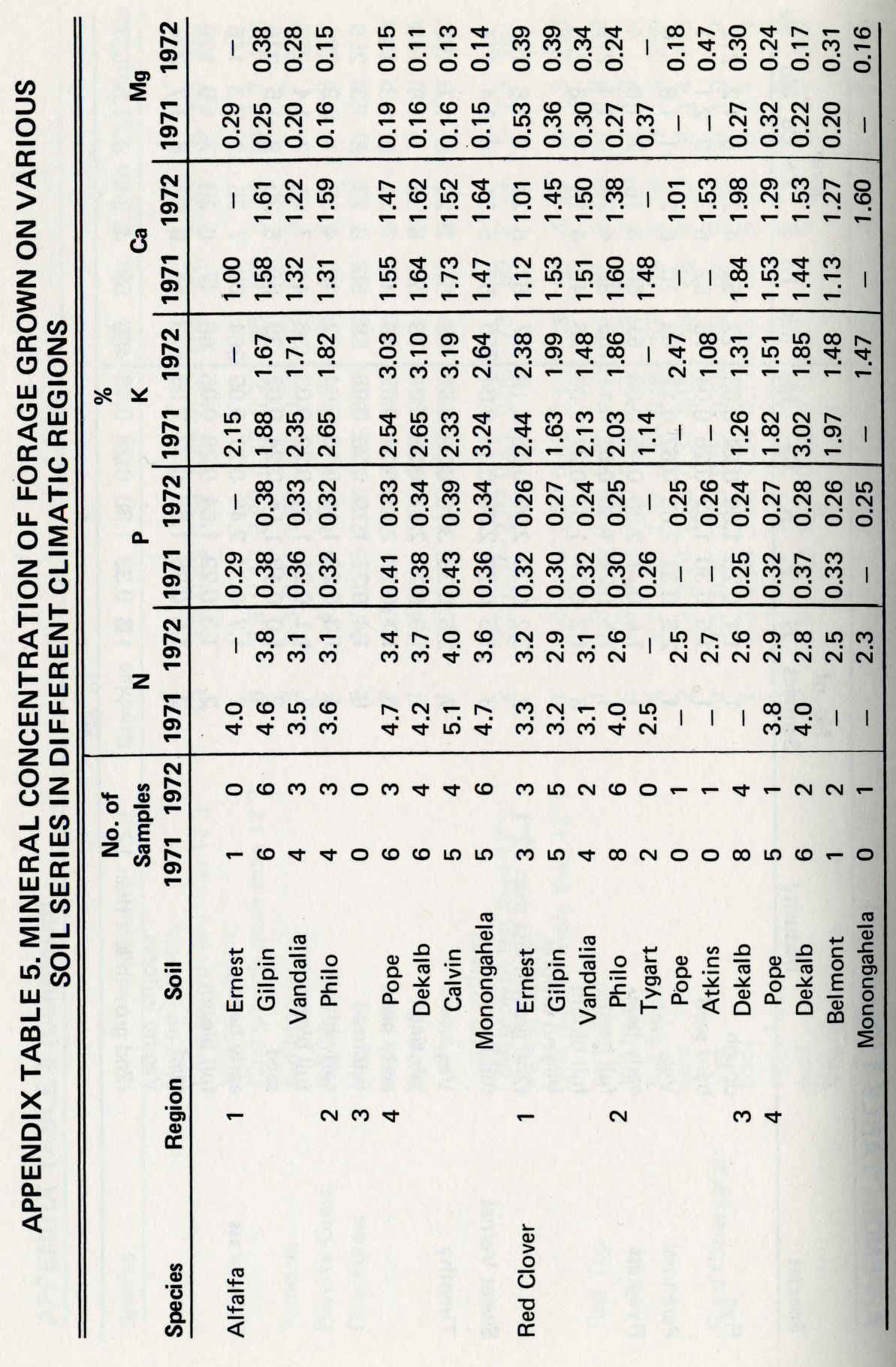

点|

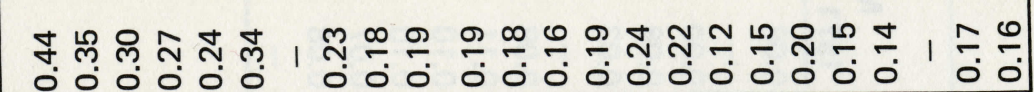
N

3

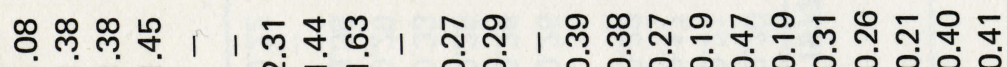
$=$

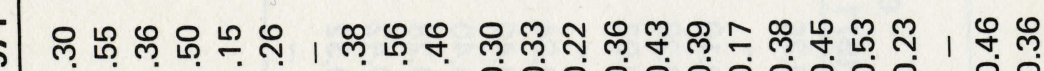

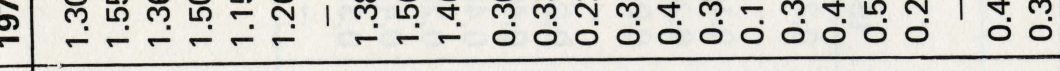
产 으

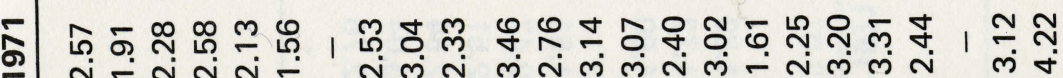

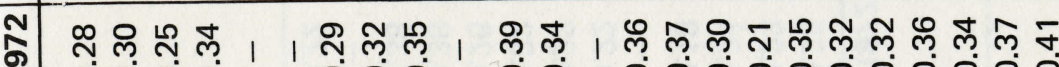

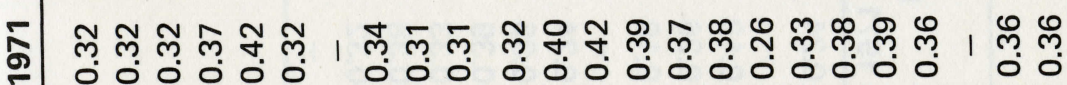
命 2 ละ

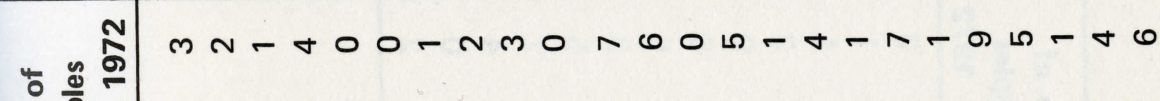

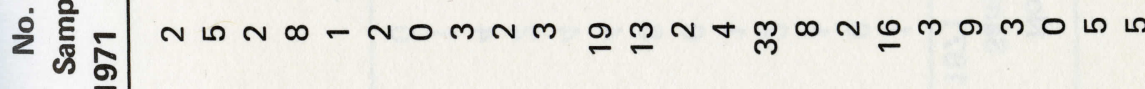

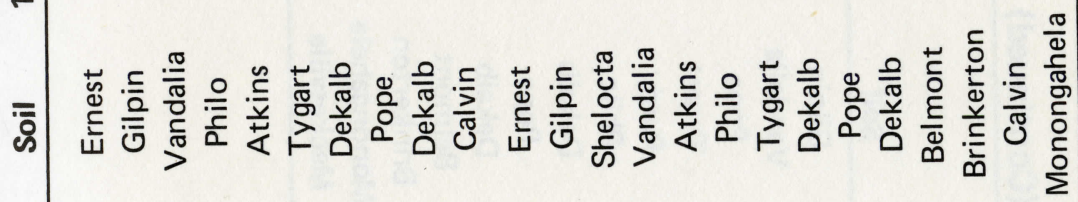

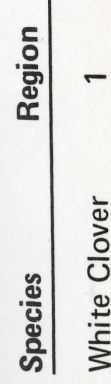

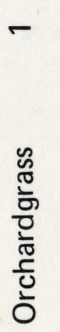
N

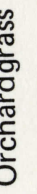




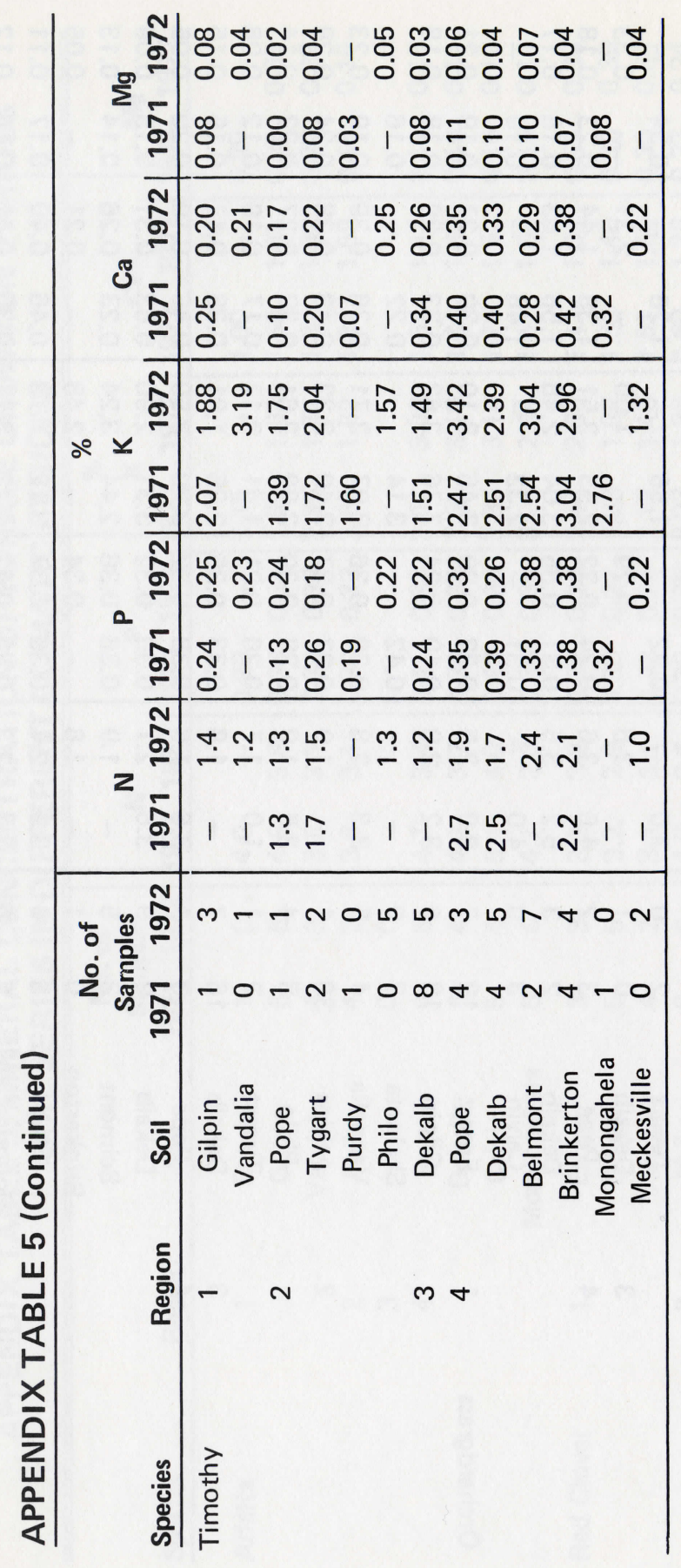

